\title{
USING INPUT-OUTPUT ANALYSIS FRAMEWORK TO EXPLAIN ECONOMIC DIVERSIFICATION AND STRUCTURAL TRANSFORMATION IN BANGLADESH
}

Valerie Mercer-Blackman, Amador Foronda, and Joseph Mariasingham

NO. 513

May 2017
ADB ECONOMICS WORKING PAPER SERIES 
ADB Economics Working Paper Series

\section{Using Input-Output Analysis Framework to Explain Economic Diversification and Structural Transformation in Bangladesh}

Valerie Mercer-Blackman, Amador Foronda, and Joseph Mariasingham

No. 513 | May 2017
Valerie Mercer-Blackman (vmercerblackman@adb.org) is a senior economist, Amador Foronda (asforonda.consultant@adb.org) is a consultant, and Joseph Mariasingham (mmariasingham@adb.org) is a statistician at the Economic Research and Regional Cooperation Department of the Asian Development Bank.

The authors thank Jasmin Sibal and Julieta Magallanes for research support, and Utsav Kumar, Zhigang Li, and Jesus Felipe for fruitful discussions. 
(C) 2017 Asian Development Bank

6 ADB Avenue, Mandaluyong City, 1550 Metro Manila, Philippines

Tel +63 2632 4444; Fax +6326362444

www.adb.org

Some rights reserved. Published in 2017.

ISSN 2313-6537 (Print), 2313-6545 (e-ISSN)

Publication Stock No. WPS178824-2

DOI: http://dx.doi.org/10.22617/WPS178824-2

The views expressed in this publication are those of the authors and do not necessarily reflect the views and policies of the Asian Development Bank (ADB) or its Board of Governors or the governments they represent.

ADB does not guarantee the accuracy of the data included in this publication and accepts no responsibility for any consequence of their use. The mention of specific companies or products of manufacturers does not imply that they are endorsed or recommended by ADB in preference to others of a similar nature that are not mentioned.

By making any designation of or reference to a particular territory or geographic area, or by using the term "country" in this document, $A D B$ does not intend to make any judgments as to the legal or other status of any territory or area.

This work is available under the Creative Commons Attribution 3.0 IGO license (CC BY 3.0 IGO)

https://creativecommons.org/licenses/by/3.0/igo/. By using the content of this publication, you agree to be bound by the terms of this license. For attribution, translations, adaptations, and permissions, please read the provisions and terms of use at https://www.adb.org/terms-use\#openaccess

This CC license does not apply to non-ADB copyright materials in this publication. If the material is attributed to another source, please contact the copyright owner or publisher of that source for permission to reproduce it. $\mathrm{ADB}$ cannot be held liable for any claims that arise as a result of your use of the material.

Please contact pubsmarketing@adb.org if you have questions or comments with respect to content, or if you wish to obtain copyright permission for your intended use that does not fall within these terms, or for permission to use the ADB logo.

Notes:

1. In this publication, "\$” refers to US dollars.

2. Corrigenda to ADB publications may be found at http://www.adb.org/publications/corrigenda 


\section{CONTENTS}

TABLES AND FIGURES iv

ABSTRACT $v$ V

$\begin{array}{ll}\text { I. INTRODUCTION } & 1\end{array}$

II. $\quad$ THE GARMENT SECTOR IN BANGLADESH 2

A. The Setup: Comparative Advantage in Trade-Embodied Value Added
and Diversification

B. Exports Don't Explain Everything 5

$\begin{array}{lll}\text { III. } & \text { LINKING GOODS AND SERVICES }\end{array}$

A. $\quad$ Input-Output Linkages and Agglomeration: The Framework 9

B. Summary Indicator of Agglomeration $\quad 23$

C. Dynamic Patterns and Development $\quad 27$

D. Promising Sectors in Bangladesh 28

E. Is Bangladesh Inserted into Global Value Chain? 29

IV. CONCLUSIONS

$\begin{array}{ll}\text { APPENDIX } & 33\end{array}$

$\begin{array}{ll}\text { REFERENCES } & 35\end{array}$ 


\section{TABLES AND FIGURES}

\section{TABLES}

$1 \quad$ Thrust Sectors

2 Participation in Production: Share of Active Sectors by Economic Activity, Bangladesh and Comparator Countries, Average for 2000, 2006, 2011, and 2015

3 Index of Agglomeration by Economic Blocks for Bangladesh and Comparators

4 Decomposed Effect of a $\$ 1$ Million Increase in Final Demand of Products in Bangladesh's Various Sectors

\section{FIGURES}

1 Curve of Value-Added Stages in the Global Value Chain for Segmented Apparel

2 Traditional and New Measures of Comparative Advantage

3 Export Concentration Ratio of Selected Ready-Made-Garment-Producing Countries

4 Agglomeration of Economic Sector-Specific Productive Activities Using the Dot-Plot Matrix Representation

$5 \quad$ Illustrative Representation of an Enclave Sector in the Dot-Plot Matrix Space

6 Backward Linkages between Manufacturing and Service Sectors and Economic Development 


\begin{abstract}
Existing literature on economic growth and structural change relies on trade data to make pronouncements about a country's competitiveness and long-term growth prospects through the acquisition of capabilities. However, insufficient data give us a limited view of what is happening within the domestic economy, and how the development of manufacturing through links in the production process leads to the export of intermediate or final products. Using input-output data, this paper devises an agglomeration indicator to measure economic diversification and to compare Bangladesh with other key economies. In the process, we shed light on the symbiotic relationship between manufacturing and services as the country develops. Despite Bangladesh's astounding growth over the past 15 years, diversification has been somewhat slower than expected for its level of development.
\end{abstract}

Keywords: Bangladesh, business services, economic diversification, global value chains, input-output tables, ready-made garments, structural transformation

JEL codes: D24, D57, F15, O14 



\section{INTRODUCTION}

Understanding the interlinkages of firms and sectors in the production process and how that leads to higher value added and trade growth has attracted increasing interest. More recently, the United Nations Conference on Trade and Development (UNCTAD) (2016) discussed this topic in the global context of changing trade patterns and development trajectories. However, most of the changes in trade patterns are the culmination of slower changes in the production processes of firms in a given countrythe "tip of the iceberg" of unobserved processes that occur within a country as small firms grow, transform, or cease to exist. Domestic firms that have developed expertise and innovation and have the broad support of institutions (in infrastructure investments, a good business climate, and supportive public policies) will eventually make it and possibly even compete via exports - these firms are typical of those included in trade data. But sparse data in developing countries make it difficult to understand how structural transformation within a particular economy over the long term changes a country's production profile and, in particular, how infrastructure and business services may be contributing to that process.

This question is particularly important for developing Asia in which many countries are emerging from low per-capita income levels to a very different environment from that of the early-to-mid 20th century during which industrialization was the path to success and development. Nowadays, automation and increasing interlinkages of global production can change the production processes and dynamics much more rapidly, particularly because of almost-perfect cross-border information and knowledge sharing. Therefore, we can witness some of these changing patterns in economic development within a relatively short time (10 to 15 years). To compound measurement problems, not only are services making up a larger share of gross domestic product (GDP) in all stages of development, but their growth is intrinsically linked to manufacturing (the so-called "servitization" of economies as discussed by Crozet and Milet 2015).

This paper looks at the case of Bangladesh, whose structural transformation has been based on the export growth of textile and garments manufacturing-in that sense, a classic development case. Using input-output data and trade in value-added measures, we find that the garment sector's astounding success has led ironically to specialization in the global context and a complete lack of diversification of the domestic economy. Unlike other comparator countries presented in this paper, Bangladesh has not been able to develop strong internal or external linkages that would enable a more diversified productive transformation, including insertion in global production chains.

Insufficient data, difficulty in measuring economic productivity, and identifying how productive firms interact across sectors are significant barriers in understanding the effects of diversification policies. This working paper is the first step of a methodology to link production processes within the country using data on international production sharing embedded in input-output tables. It also explores what happens to sectoral linkages through the production process when a particular sector begins to thrive-in particular, how business services, infrastructure services, and education and community services respond to growing export-oriented sectors. We find that Bangladesh could benefit from developing a tradition of business services more actively, particularly producing intermediate goods such as machinery components and auto parts.

The paper is organized as follows. Section I summarizes Bangladesh's ready-made-garment sector and its role in the country's development over the past 15 years. Section II describes how this relates to measures of comparative advantage, gives an understanding of economic diversification and sophistication, and summarizes related literature. Section III describes the methodology used to define 
economic diversification and insertion in global production chains, and explains the results and implications for growth and links to other sectors going forward. Section IV concludes.

\section{THE GARMENT SECTOR IN BANGLADESH}

Over $80 \%$ of Bangladesh's export growth between 2000 and 2015 can be attributed to the ready-made garments (RMG) sector. This astounding growth has created millions of manufacturing jobs and has made Bangladesh the second-largest garment exporter in the world in 2014 from being only in 76th place in 1980. The share of RMG and textiles in total exports rose from 57\% in 1980 to over $80 \%$ in 2015. Other manufacturing exports, such as footwear and pharmaceuticals, grew quickly in the 10 years through 2015, but the RMG sector dwarfed the size of their growth. The Multi-Fiber Arrangement (MFA), the policy that calls for the creation of a special bonded-warehouse system designated RMG as a 100\% export-oriented industry and created a duty-free environment for the sector even while huge tariff and nontariff barriers affected the rest of the economy. The MFA was eliminated in 2005, but export growth continued. Moreover, income from RMG enterprises is exempt from taxes.

Nonetheless, this success was also partly the result of many government incentives that have continued to this day despite the sector's prominence in the economy. The Government of Bangladesh has followed the same industrial policy of supporting the five most dynamic (fastest-growing) sectors, a strategy that reinforces differences in growth across sectors but may neglect sectors that have potential but with specific barriers that need attention. Table 1 shows these sectors from the 2016-2020 FiveYear Plan.

Table 1: Thrust Sectors

(\%)

\begin{tabular}{|c|c|c|c|c|}
\hline Input-Output & Economic Block & $\begin{array}{c}\text { Average Growth } \\
\text { Rates, } \\
2000-2011\end{array}$ & $\begin{array}{c}\text { Share of Gross } \\
\text { Value Added }\end{array}$ & $\begin{array}{c}\text { Share of } \\
\text { Employment }^{a}\end{array}$ \\
\hline Telecommunication & $\begin{array}{l}\text { Infrastructure } \\
\text { service }\end{array}$ & 20.8 & 1.6 & 0.1 \\
\hline Chemical products & Manufacturing & 10.0 & 1.0 & 0.3 \\
\hline $\begin{array}{l}\text { Textiles and ready-made } \\
\text { garments }\end{array}$ & Manufacturing & 9.2 & 7.0 & 8.3 \\
\hline Transport equipment & Manufacturing & 6.9 & 0.7 & 0.1 \\
\hline $\begin{array}{l}\text { Leather products and } \\
\text { footwear }\end{array}$ & Manufacturing & 4.3 & 0.5 & 0.2 \\
\hline
\end{tabular}

The productivity of the RMG sector is based on low fixed costs and labor-intensive manufacturing processes, which puts the country's production process squarely at the bottom of the global fashion value chain. By nature, the fashion business is a classic buyer-driven global value chain. Unlike producer-driven value chains, in which scale, volume, and technology are major determinants of profit, the buyer-driven global apparel value chain brings profit opportunities for specialized services at the beginning and end of processing. In other words, retailers, designers, and managers leverage their talents in high-value research, design, sales, marketing, and financial and retail services to strategically link overseas factories and traders (the supply side) with their mass-market product lines. This includes 
importers, wholesalers, business associations, and other service providers-logistics, consultancy, academic institutions, law firms, transport, testing and certification companies, and promotion agencies. Bangladesh's RMG firms are only one component of this complex global value chain. These firms also happen to specialize in the cut-make-trim process, the lowest stage in the production chain in terms of value.

There are two possible ways through which a manufacturing sector in a developing country can create more value added in production: either by moving vertically ( $B$ in Figure 1 ) or horizontally ( $A$ in Figure 1). Moving vertically implies progressively moving up the global value chain to more sophisticated stages of the production process in the same line of goods or services. Moving horizontally means the country learns to develop capabilities in another good or service that is in a different sector but perhaps requires similar skills and, in this way, creates more value (Hausmann and Hidalgo 2011). Over time, the country may develop a comparative advantage in this new activity. Figure 1 shows that, given the structure of the fast-fashion industry, the chain is segmented: it is difficult for Bangladesh to move vertically. In this paper, we suggest instead that it is possible for a country like Bangladesh to move horizontally if it can create links to forge across sectors, which in essence is economic diversification. Through agglomeration of related firms, diversification will unleash growth in new sectors, which may eventually develop a comparative advantage in embodied trade in value added.

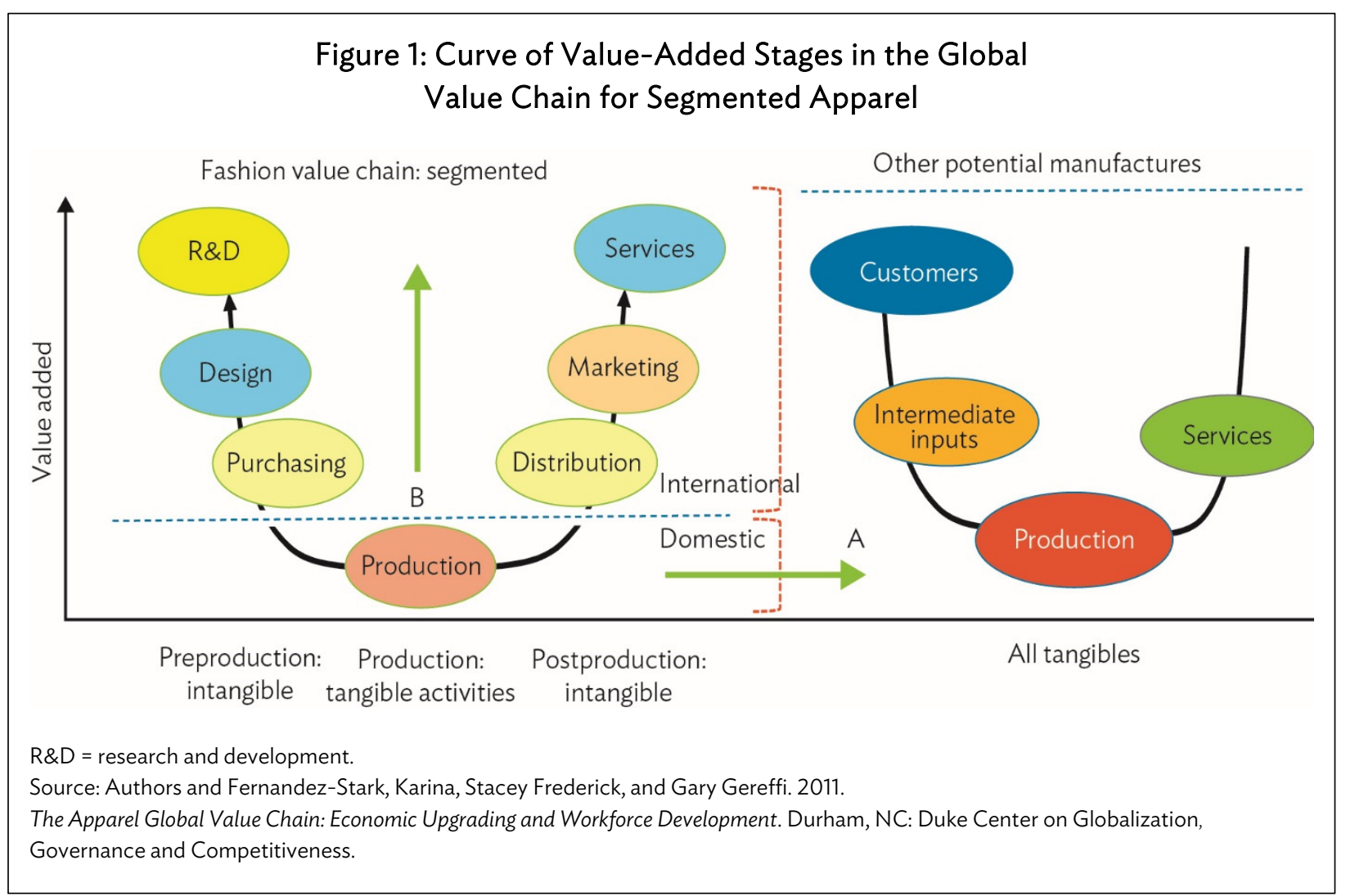

1 Pressure to produce within short turnaround times and at very low prices provides the "perfect storm" for production mishaps. Some of these lead to many accidents, culminating in the April 2013 Rana Plaza incident. Since then, wages for RMG workers have risen by about $40 \%$ and compliance with basic safety codes have improved, but costs are still very low. 
But how much does diversification of exports really matter? In the following section, we suggest that only to the extent that it is the result of a process of economic diversification, which does matter for sustained structural transformation. ${ }^{2}$

\section{A. The Setup: Comparative Advantage in Trade-Embodied Value Added and Diversification}

To succeed in the export market, a sector has to undergo a series of stages of growth and nourishment. Generally, indicators of revealed comparative advantage are used to measure success. We compute the indicator developed by Wang, Wei, and Zhu (2014) and ADB (2015) to measure the comparative advantage of various sectors in Bangladesh. A sector's relative comparative advantage can be measured using a traditional method (by looking at how an exported product compares with other products), or by computing the value of the product created by a country and embodied in an export, regardless of whether the final export originated in the country in question (see Appendix for the detailed derivation of the indicators)

According to traditional measures of revealed comparative advantage (TRCA-equation 7 in the Appendix), Bangladesh is clearly very competitive-it is the most competitive producer of most garments after the People's Republic of China (PRC) and the most competitive country for basic garments such as t-shirts (ADB 2016a section 5.2). However, any embodied service that was included in the value added after it was exported would be excluded in that TRCA measure.

We define the new indicator that measures trade-embodied value added, as new trade in valueadded revealed comparative advantage (NRCA) (equation 8 in the Appendix). The NRCA splits the production process into its various components and appropriately attributes to each country the value added they contributed. A simple example is the iPhone: the PRC produces the glass screen and assembles the final product ready for export, but behind the production of an iPhone there is much know-how, mainly produced in the United States (US). In the TRCA formula, we measure the comparative advantage in exports of the full iPhone, whereas in the NRCA only the value of the glass screen and assembly services of the product in the PRC is attributed to the PRC and compared with other countries that also produce glass screens and assemble iPhones. Hypothetically, the PRC may not have a comparative advantage in the export of smartphones, but it may have a comparative advantage in glass screen production and assembly. In the latter case, the revealed comparative advantage indicator is correctly attributing the productivity of the country to that good or service, even if the good or service is not exported.

The results of both measures for the textile and garment industry in selected export countries can be seen in Figure 2. It shows that Bangladesh has a comparative advantage relative to other countries using either measure (the NRCA or the TRCA). Because RMG production is a relatively simple manufacture, most of the production is completed in one country, so the results provide a similar picture of the revealed comparative advantage (RCA) of the other textile and garment producers. The results establish unequivocally that Bangladesh RMG exports are very competitive, and ADB (2016a) shows

2 This segmentation also exacerbated the dissociation between the unit cost of production and its retail price, and Bangladesh's ability to move up the value chain. As long as the big buyers maintain price-setting power, garment makers have no incentive to upgrade facilities or enhance workers' skills because race-to-the-bottom cost-cutting measures will always take precedence to guarantee a firm's survival. Moreover, because of the focus on meeting orders on time, firms have little leeway to become more proactive in anticipating buyers' needs. Critical activities that could help Bangladesh RMG move beyond the cut-make-trim template, such as investing in research and development and developing local design and pattern-making capabilities, are not pursued. In sum, RMG workers have limited exposure to technical knowhow in the knitwear industry because they have few opportunities for advancement. 
that it is based on low production costs. Consequently, export growth has surged, leading to the dominance of this sector in exports. The next section discusses whether we should be worried about this phenomenon.

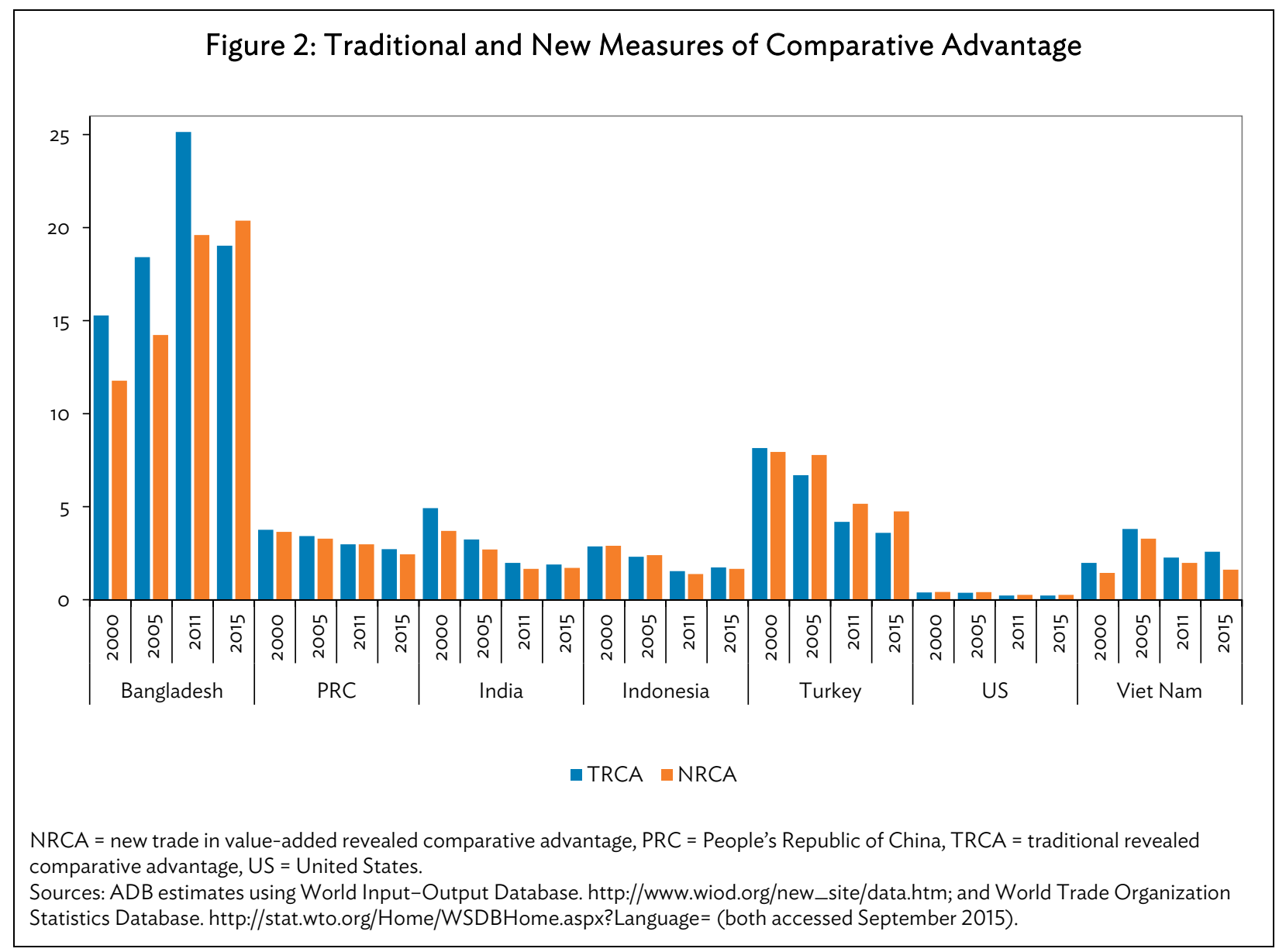

\section{B. Exports Don't Explain Everything}

In much of the policy discussion, not just in Bangladesh but elsewhere, there is an implicit notion that export diversification is an important objective for a country, but the reasons are not always specified clearly. They point to indexes of export concentration such as the Herfindahl-Hirschman Index (Figure 3). The economic literature can also provide seemingly conflicting implications about diversification. On the one hand, specialization seems to convey sophistication and learning-by-doing. There is a sense in which economies of agglomeration and specialization lead to "spillovers" and externalities which lead to growth, either by fostering healthy competition or by providing a critical mass of skills. On the other hand, from a macroeconomic and stability perspective, "putting all your eggs in one basket" leads to sharp fluctuations in economic activity (booms and busts) that are exacerbated if the commodity produced by the country is also the one that generates the most foreign exchange, fiscal revenue, and employment.

Emphasis in economic literature on the virtues of exporting comes from evidence suggesting that higher exports are a manifestation of production sophistication and competitiveness. First, export diversification is considered the culmination of a number of factors (Hausmann and Hidalgo 2011). 
One can equate observed sophistication of exports across product space as a sign of innovation and complexity. Felipe and Kumar (2012) equate the diversity and sophistication of products manufactured by a specific country with its per capita GDP, with the implication that the greater the variety of products exported and the closer they are to the structure of a rich country's product space, the more it signals that a country's development is going in the right direction. ${ }^{3}$

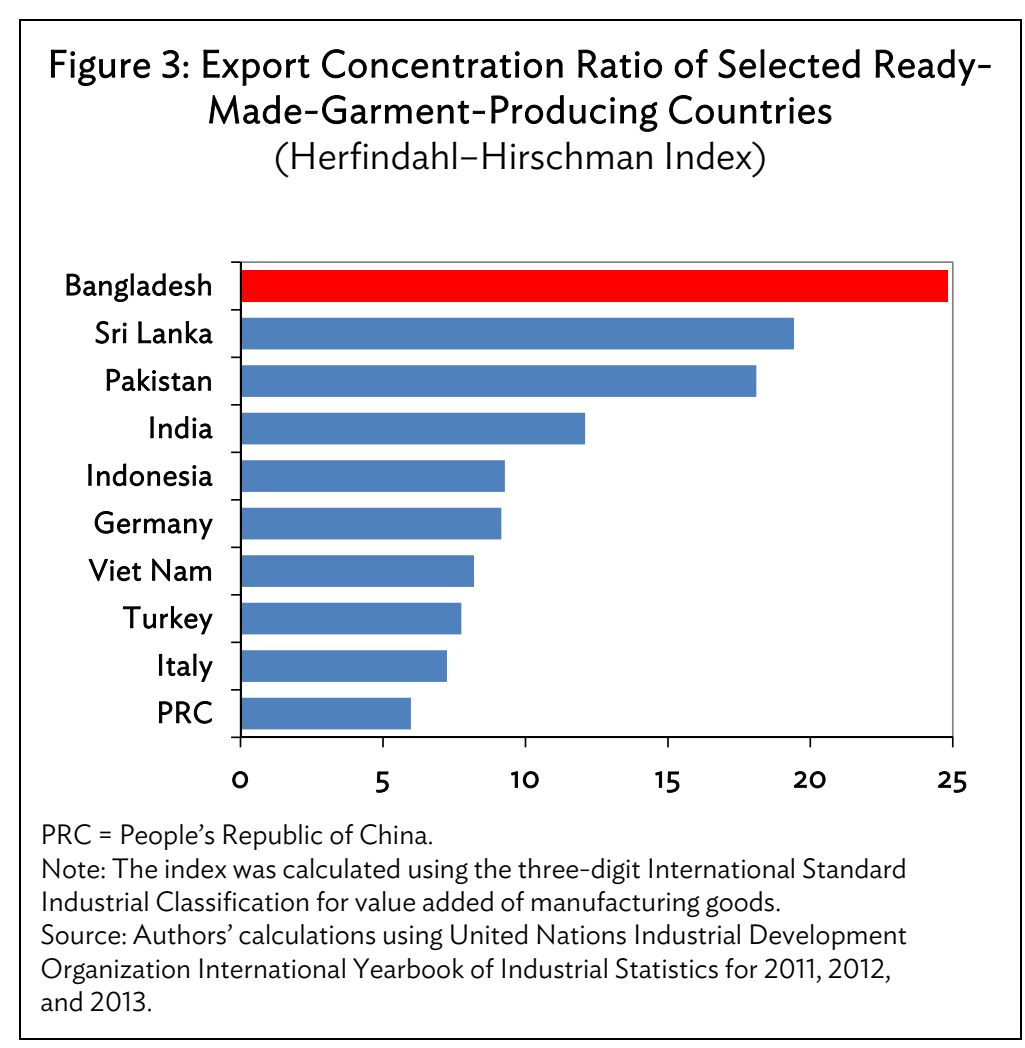

While this argument is valid and has substantial empirical backing, the tendency in the literature to discuss exports many times has to do with the relatively good availability of export and import data, which contrasts with data on firms or production of sectors. Trade data, rather than domestic production structures, are oftentimes used to make inferences about a country's domestic productivity, sophistication, and even structural transformation. This also stems from the difficulty of gathering evidence on the role of domestic production structures, which overwhelmingly are services. Moreover, if exporting is the culmination of a firm or sector's increasing competitiveness in the domestic economy, policy makers ideally need to discover the features and characteristics of the production and employment structure before that country can begin to ramp up exports successfully.

More specifically, inferences using trade data do not necessarily provide a good picture of the links within an economy. These are mostly related to the difficulty of measuring productivity in sectors of the domestic economy and include the following:

(i) Most of the evidence comes from very detailed trade data, which generally measure only trade in goods. However, services are not only becoming an increasingly important part of international trade, and various "support" or knowledge services for industries may

3 They find that the complexity of a product is a function of the capabilities it requires, while the complexity of a country is given by the number of locally available capabilities. 
not be directly traded, yet they make up an important part of the value of a good or service traded. Data on this are scant, even less so data that bear cross-country comparison; and little detail exists on the "value" linkages of different goods or services.

(ii) In many developing countries, notably Bangladesh, a large portion of the economy is informal, with many services going undetected by business registries, tax authorities (perhaps because they have no tax liability), or statistical agencies. This is particularly true in economies where most of the transactions are on cash basis. Consequently, a Bangladeshi web-based software designer contracted by a company overseas has added value to the operations of that company, but their income may not be captured as a service in the Bangladesh national accounts.

(iii) The treatment of machinery and transport equipment is different in developing countries, because their low-cost labor allows for the repair and continued operation of machines which in developed economies would have outlived their operational life. National accounts data generally do not capture those savings directly because actual depreciation rates will be lower in Bangladesh.

(iv) Learning-by-doing and specialization is something more readily observable in clusters of advanced economies, but may be mismeasured in developing countries. An innovation may be occurring in the cities of developing countries but the value added is not recorded. Consider the "reverse innovation" of a wheelchair in India (Winter and Govindarajan 2015): Engineers in India reengineered an expensive wheelchair to make it suitable for India's bumpy roads and removed some of the "bells and whistles" that Americans need but Indians may find unnecessary given available domestic or family help. Doing so could reduce the wheelchair's price. If valued at the selling price in India, that machine would have shown a relatively lower value added than in the US, yet the cost savings were an innovation for the local market.

(v) The degree of diversification is by nature specifically related to the use of a country as a unit of analysis. In some ways, the economics literature in general does not implicitly account for the size of markets when comparing countries: one expects the PRC to be more diversified than Luxembourg, as it is many times larger. Yet, towns the size of Luxembourg within the PRC may not be diversified.

(vi) Finally, at the level of 35 sectors, a country may not seem very specialized, but within a particular sector, sophistication, talent, and knowledge spillovers may be enormous (such as Malaysia's petroleum service sector, for example).

\section{LINKING GOODS AND SERVICES}

This section describes the framework for identifying sectoral links and the diversification into more products. We also illustrate how services are really a set of supporting industries that can strengthen links across the economy and can contribute to economic diversification and eventual growth in new sectors. Moreover, as service sectors become more important globally, countries can engage in increasingly complex business-related services without having to export them, particularly in an era of full global communication.

The framework should allow us to understand how the development of one sector in an economy can help develop others through links, and ultimately illustrate the process of sectoral development of a country. First, one should see how a sector's growth has led to new skills and the creation of parallel activities either through forward links (reverse engineering of knitting machines, for example) or the "pull" factor of infrastructure services and business services. In other words, it 
stimulated production in related sectors. Infrastructure investment and improvement of ports may go hand in hand with RMG growth and investment, which could support new sectors. Once new activities are created, in the process of structural transformation, some will move to export markets and may develop a comparative advantage. The framework thus also allows us to identify the new sectors created and determine how competitive they are internationally-whether as a direct export, or as an indirect support service to other direct exports. The latter should have a high score on the NRCA indicator. Moreover, as countries move up the income ladder, the proliferation of activities related to business and professional services will be evident in a high services NRCA score.

In addition to Bangladesh, we extend the analysis to the PRC and Viet Nam (which have been extremely successful in diversifying their production structures), India (which has some historical similarities to Bangladesh as well as a thriving garment sector), and the US (as a prototype of an advanced economy).

\section{Related Literature}

With the World Input-Output Tables, several new papers have examined the production structure of particular economies. Feenstra, Inklaar, and Timmer (2015) measure total factor productivity by sector and relate it to trade flows and economic growth. Fadinger, Ghiglino, and Teteryatnikova (2015) look at how differences in input-output structure and sectoral productivity translate into income differences. They find that the sparse input-output structure of low-income countries helps to mitigate impact of very low productivity levels on some sectors (similar to our methodology except we differentiate the effects of manufacturing and service sectors). Finally, Boehm, Dhingra, and Morrow (2016) test for firmlevel capabilities that are shared across products and manifested through input-output linkages. For India, they show that a firm's idiosyncratic horizontal and vertical similarity to a product's input-output structure predicts product adoption.

Perhaps the most similar study to ours is Bartelme and Gorodnichenko (2015), which documents a strong and robust relationship between the strength of industry linkages and aggregate productivity. They find that distortions - which act as taxes on revenue or intermediate input usagereduce the multiplier effect of the input-output linkages. In other words, government intervention can affect the pull or push effect of intermediate demand. This makes statistics based on the input-output entries potentially powerful indicators of the presence of distortions in the economy.

In this analysis, we are not able to directly explain why some linkages are stronger than others and even less whether they are due to policy distortions. Within an economy, the linkages are determined by the most cost-efficient production technology specific to an industry and product. However, if the policies are effective and some of the basic elements of an "economic ecosystem" are in place, innovative sectors should be able to develop and eventually penetrate export markets. The analysis also illustrates how quickly an economy has developed and transformed structurally over the span of 15 years, with each sector increasing its contribution to the economy by participating more in the production processes of other industries or sectors. ${ }^{4}$

4 A country may need to have the right conditions to develop innovative sectors: good "infrastructure" for education; transport (land, air, and water); utilities; the legal framework (rule of law); stable governance; and so on. Only then can it attempt to gain comparative advantage by developing the most cost-efficient and competitive production processes (in terms of quality of output). 


\section{A. Input-Output Linkages and Agglomeration: The Framework}

Input-output tables depict the interactions among industry and institutional sectors of an economy. They can be used to study the linkages between traded and nontraded sectors and analyze possible intersectoral spillovers. They do so even intertemporally and interspatially, depending on data availability. They offer a powerful tool once a variety of econometric, statistical, and mathematical methods are applied, which helps to understand the functioning and evolution of an economy. To understand how a particular productive sector evolves into a significant exporting one, it is necessary to study its role in the domestic economy.

For this exercise, the economy is divided into the 35 sectors from the World Input-Output Database, except that the sectors are ordered according to how "tradable" they are: agriculture and natural resources are listed first, then manufacturing, the key sector at this juncture of Bangladesh's economic development, and finally, services. In turn, manufacturing activities are ranked according to the sophistication of the goods produced as defined by the Economic Complexity Index of Hidalgo and Hausmann (2009). ${ }^{5}$ The services are divided into supporting infrastructure such as transport and telecommunications, and so-called business services, which include the finance sector, real estate, wholesale and retail trade, rental and leasing of machinery and equipment, and other business activities. Activities of the labor force engaged in professional services are likely related to the supplies of these sectors. Finally, government and community services, including education, are listed at the end given that, generally speaking, public services provide support to the productive sector only indirectly.

Consider a unit-value change in the demand for the products of each sector (demand shock). So as to respond to that shock, the output of the sector being considered as well as that of other sectors supplying it will change. Let's take "textile and garments," which are labeled "TRMG." There could be two extreme supply-use scenarios: either it only demands intermediate inputs from itself, or it demands from every single sector of the economy an amount that is more than just negligible (Figure 4).

5 The Economic Complexity Index, developed by Hidalgo and Hausmann (2009), is a holistic measure of the production characteristics of a large economic system (either a country, a sector, or a product). The index combines the metrics of the diversity of countries and the ubiquity of products to create measures of the relative complexity of a country's exports. 
Figure 4: Agglomeration of Economic Sector-Specific Productive Activities Using the Dot-Plot Matrix Representation

(4.1) Bangladesh, 2000

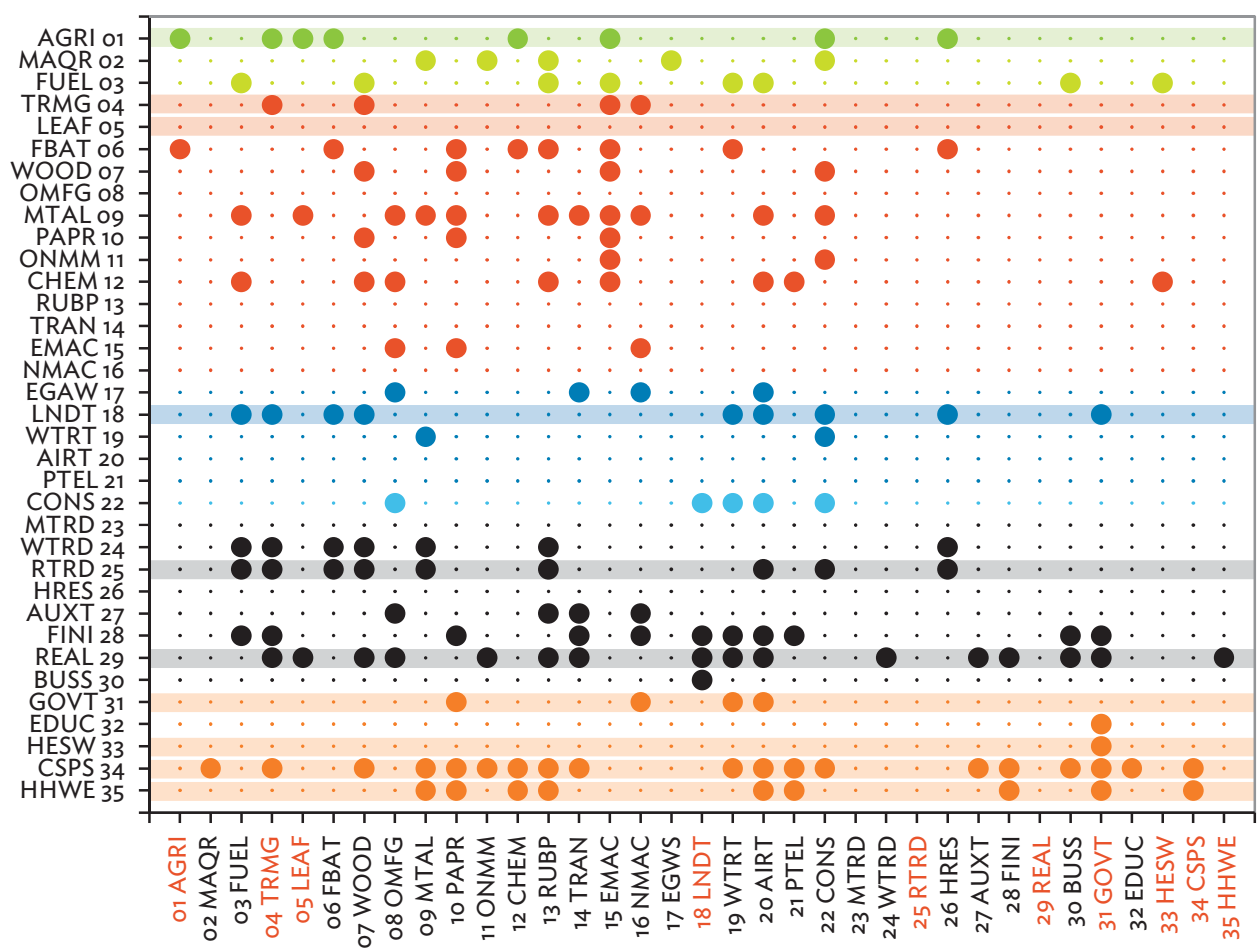

(4.2) Bangladesh, 2006

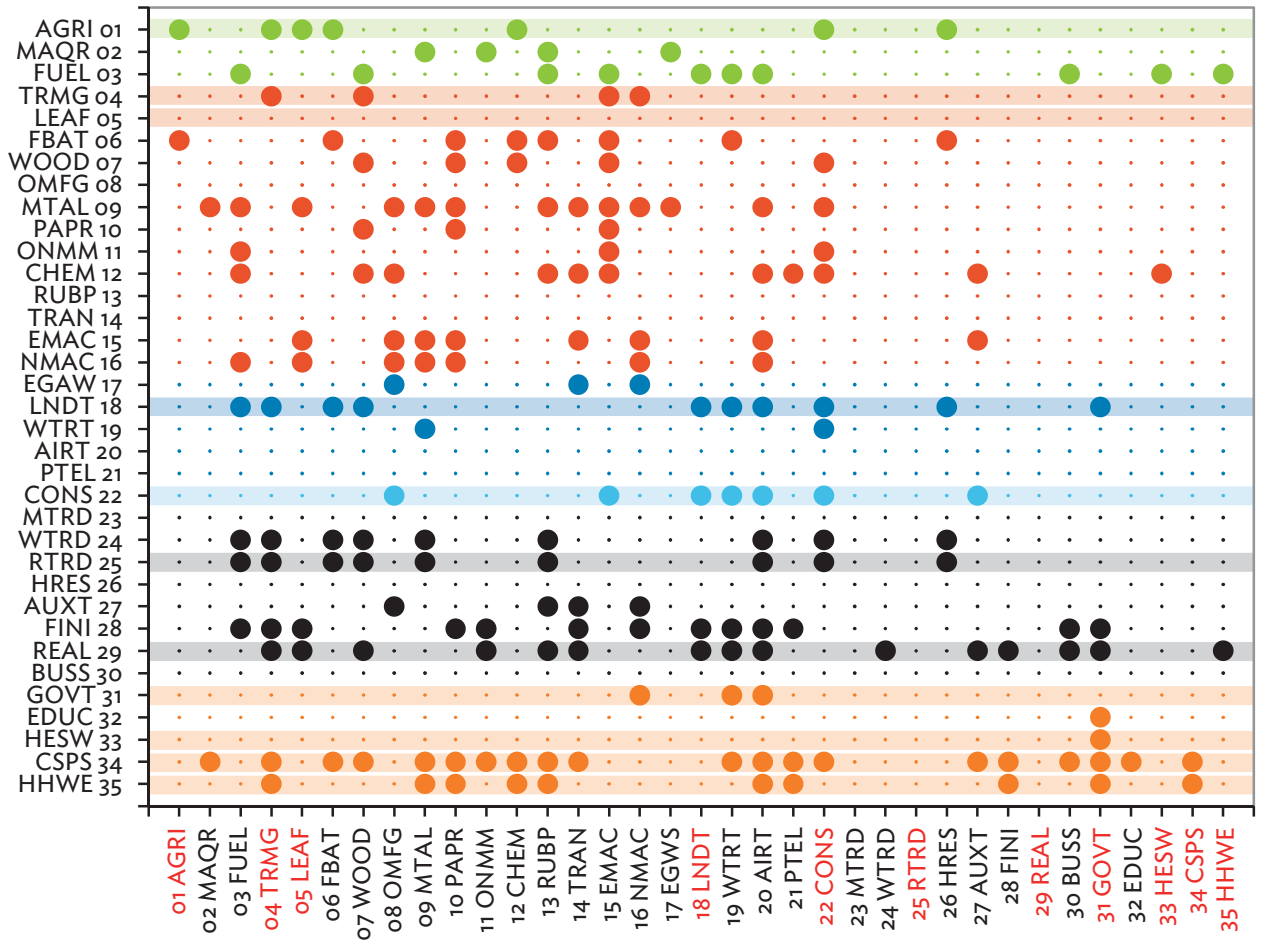


(4.3) Bangladesh, 2011

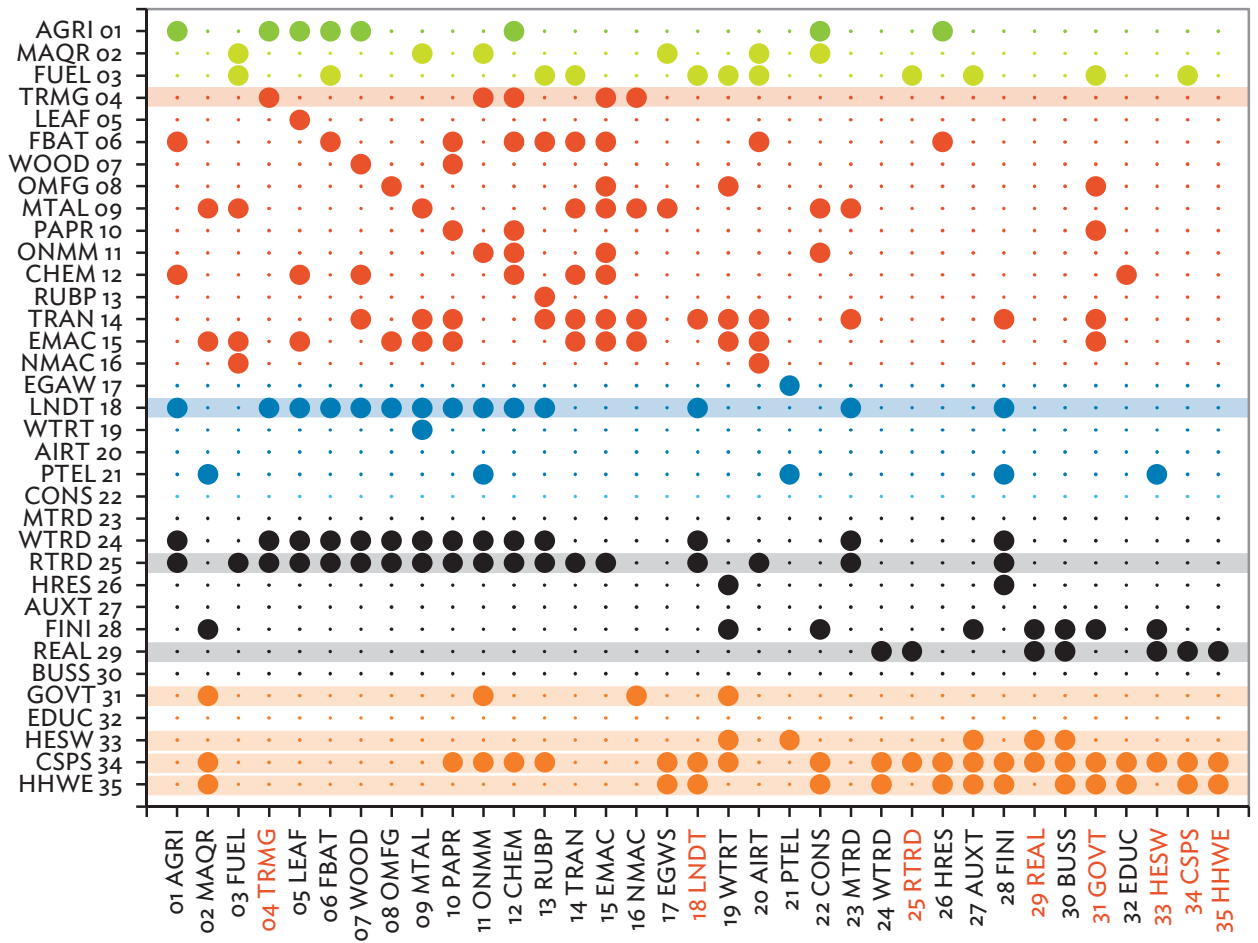

(4.4) Bangladesh, 2015

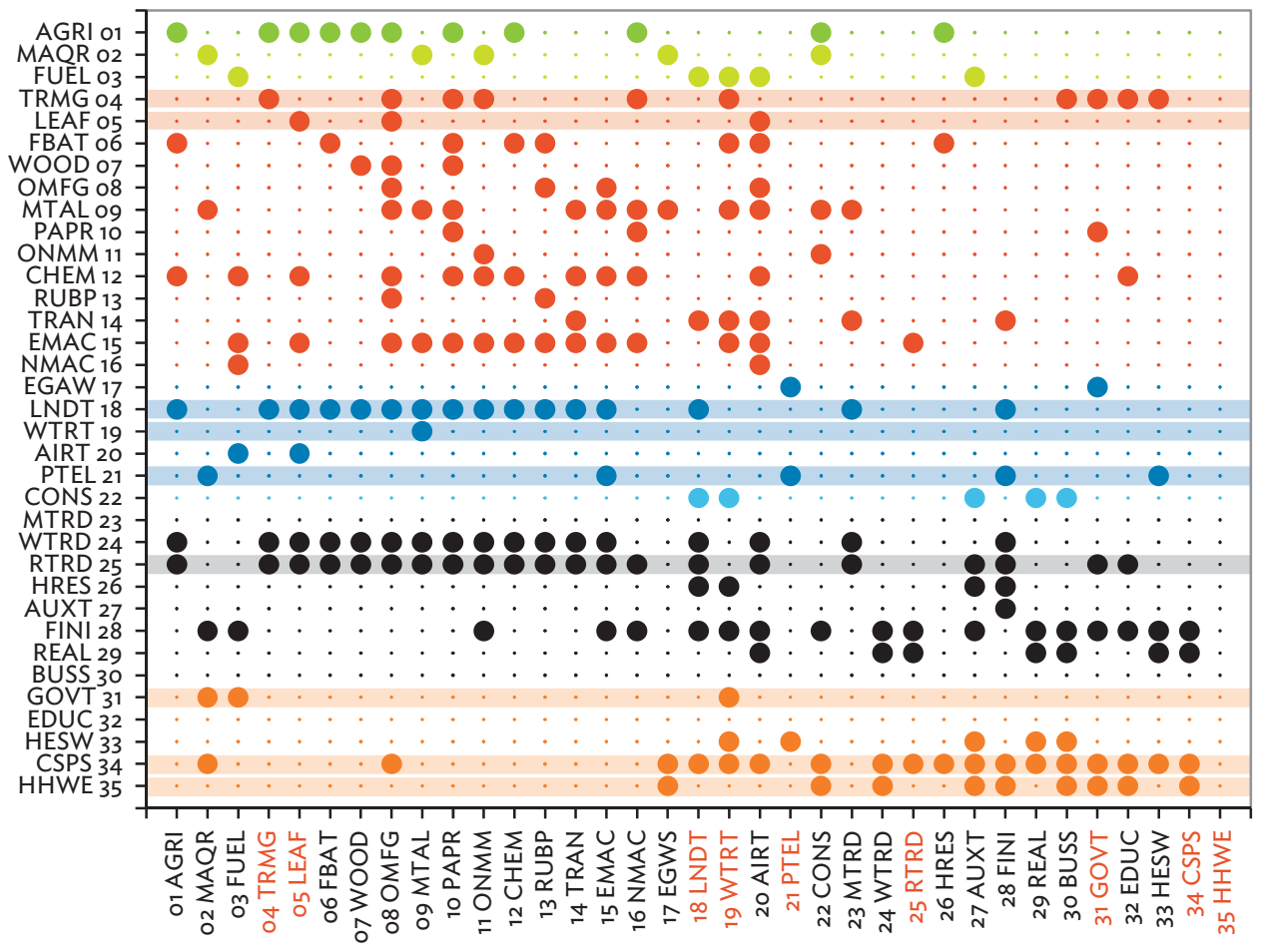




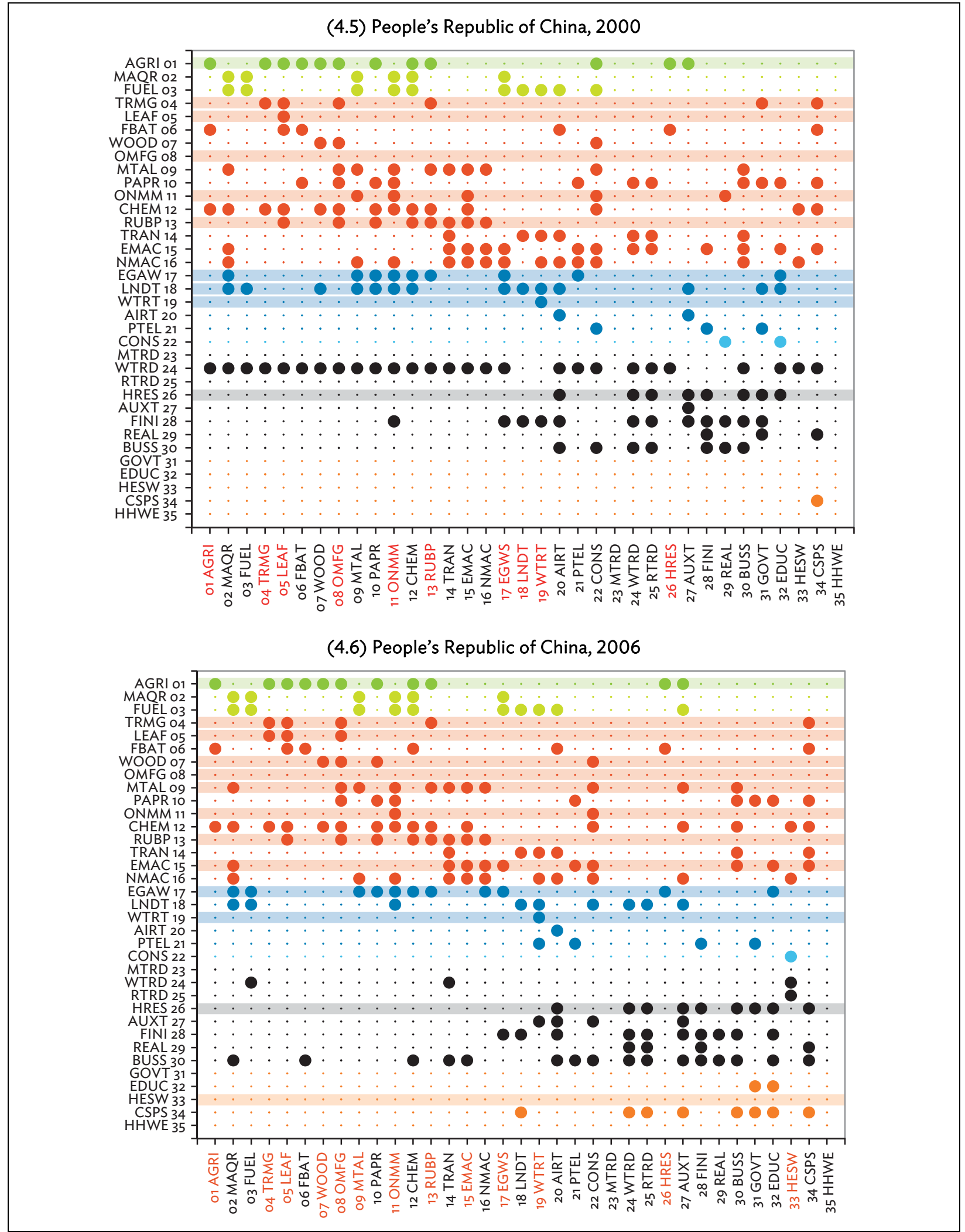


(4.7) People's Republic of China, 2011

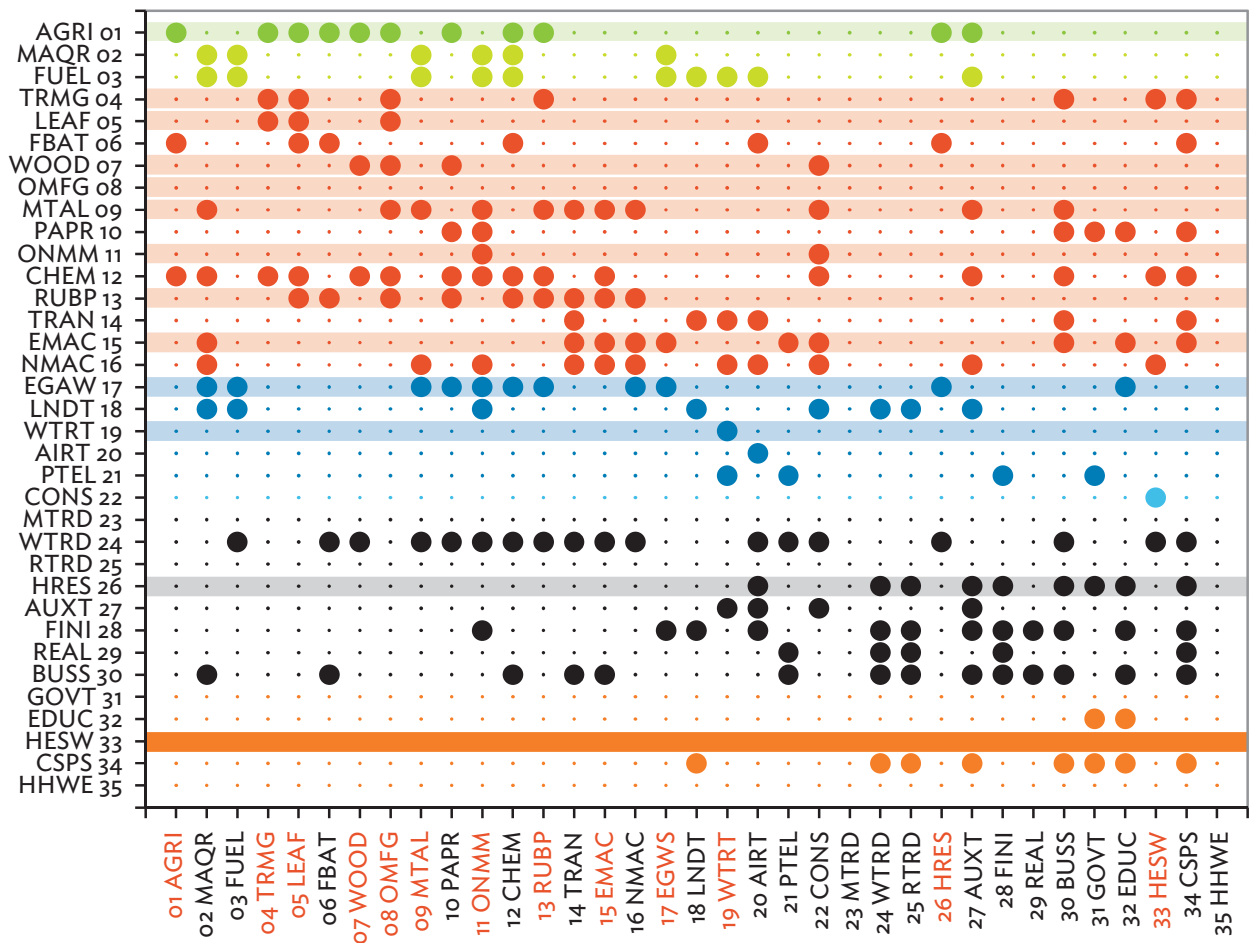

(4.8) People's Republic of China 2015

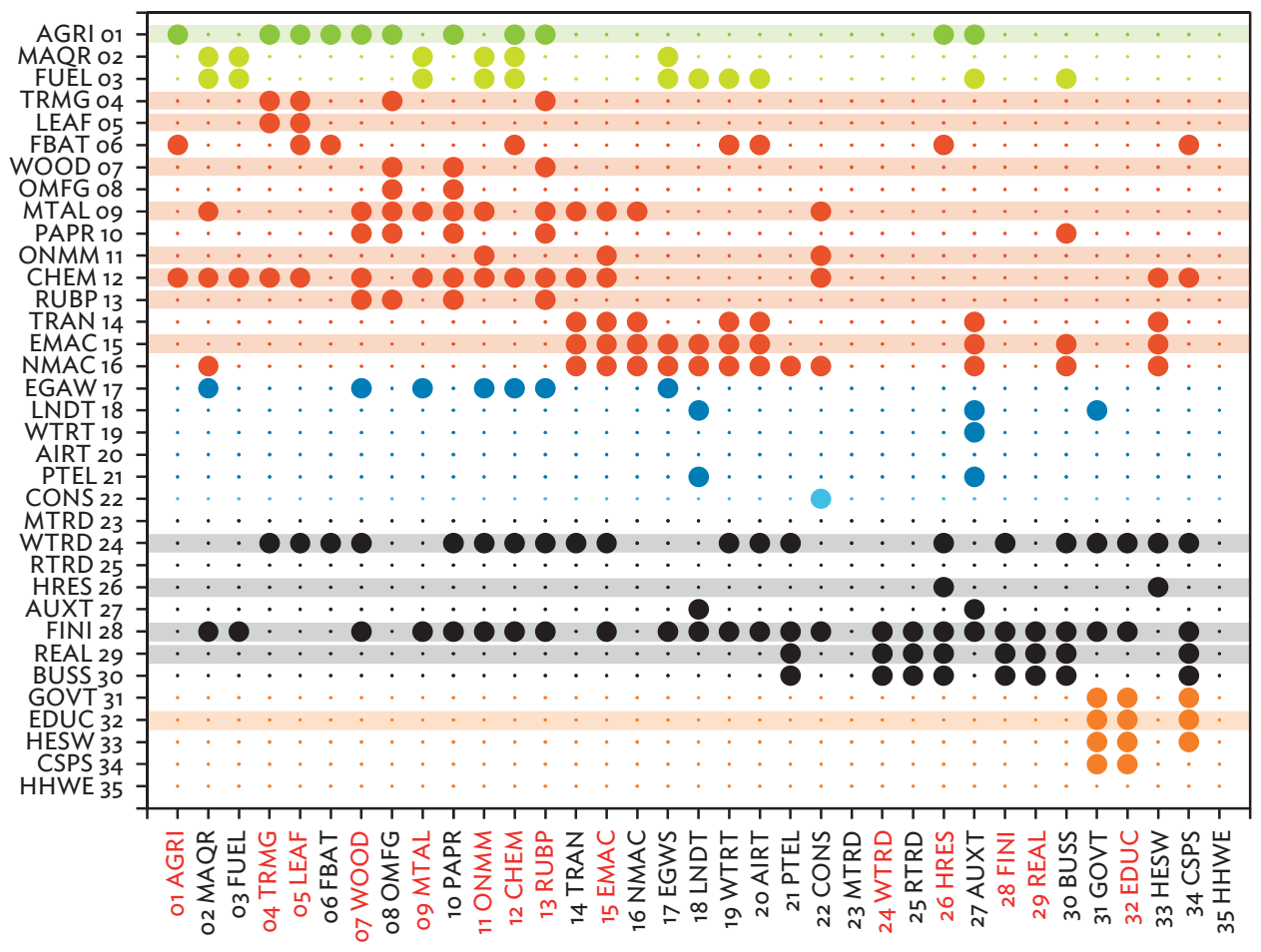


(4.9) India, 2000

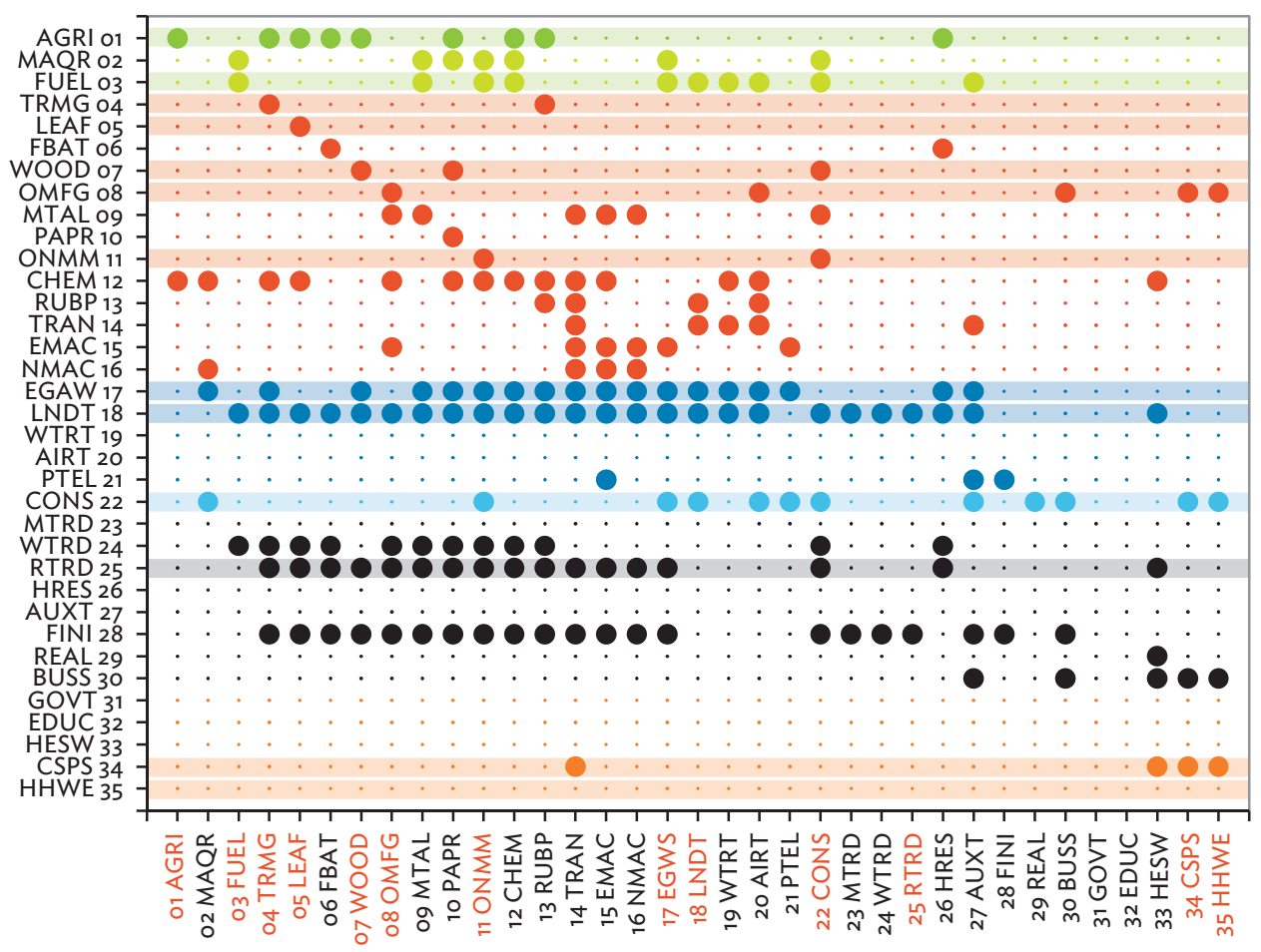

(4.10) India, 2006

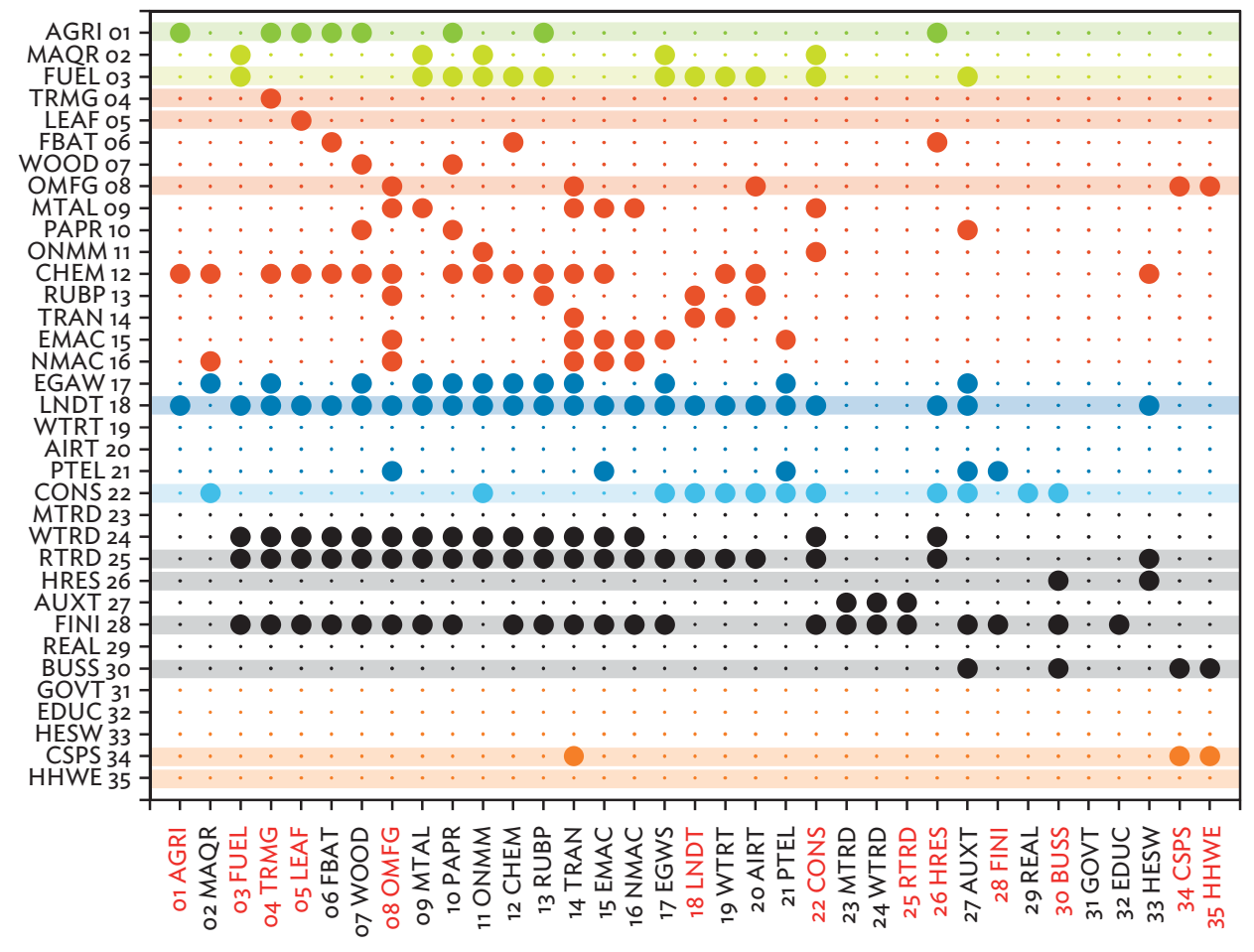


(4.11) India, 2011

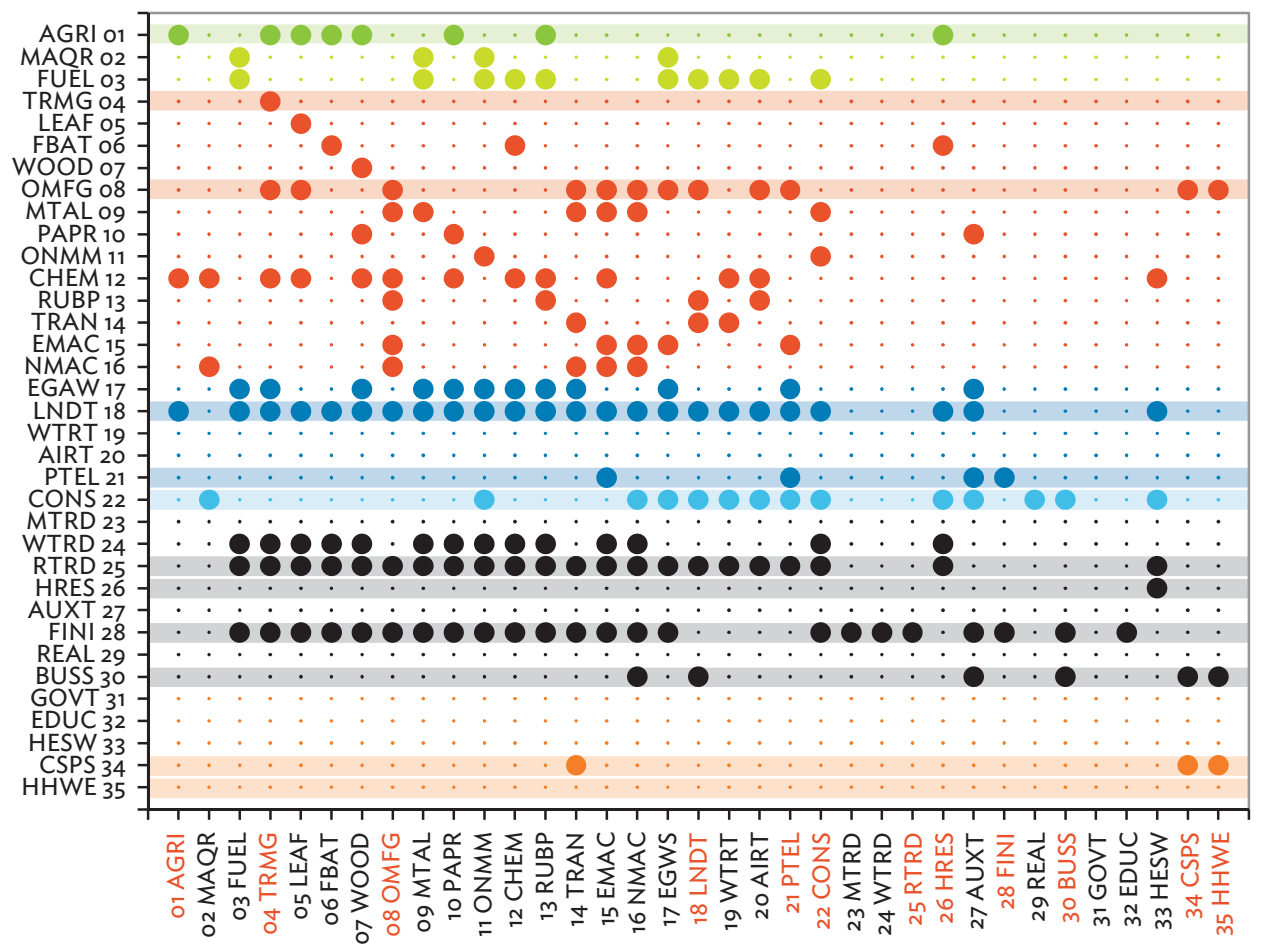

(4.12) India, 2015

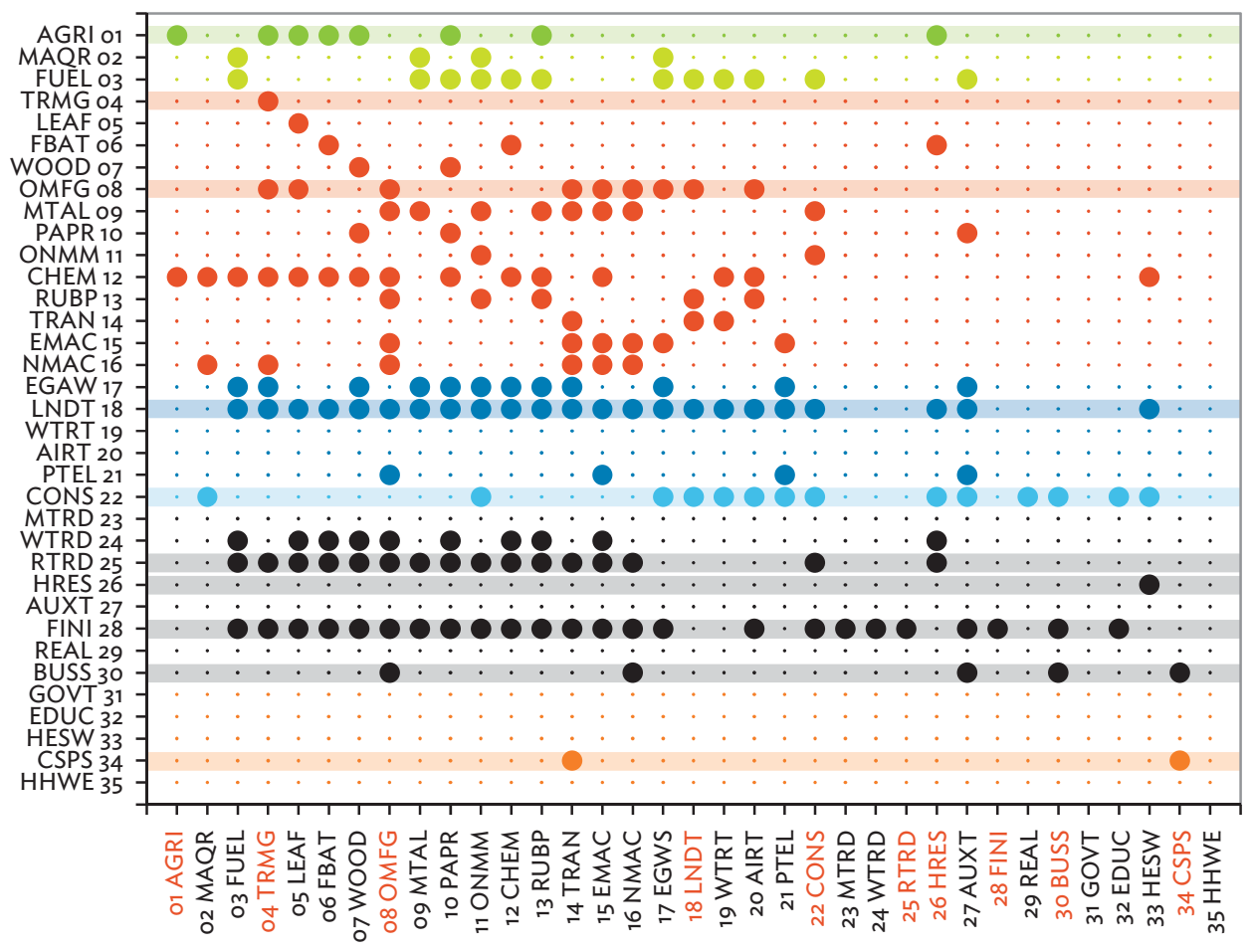




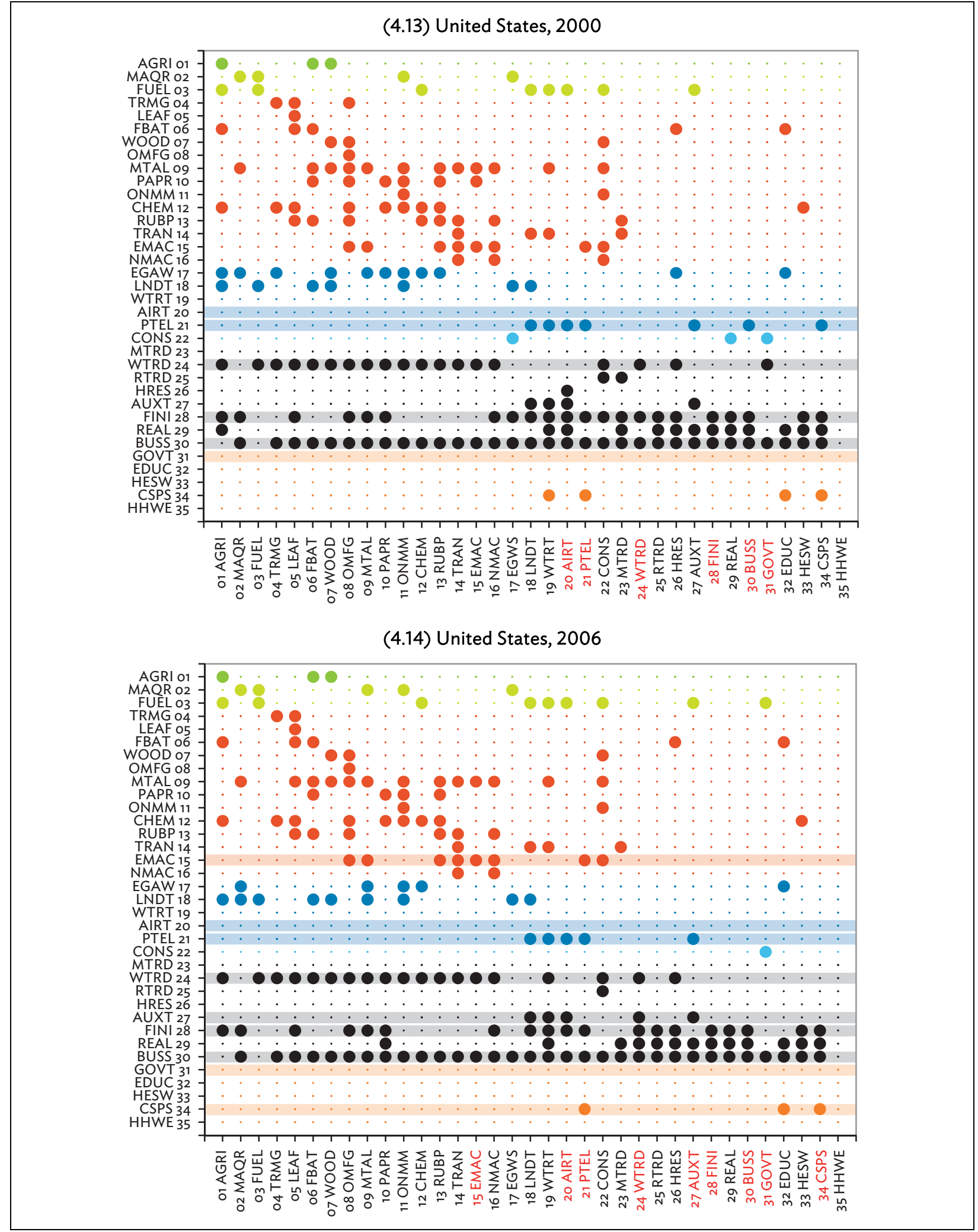




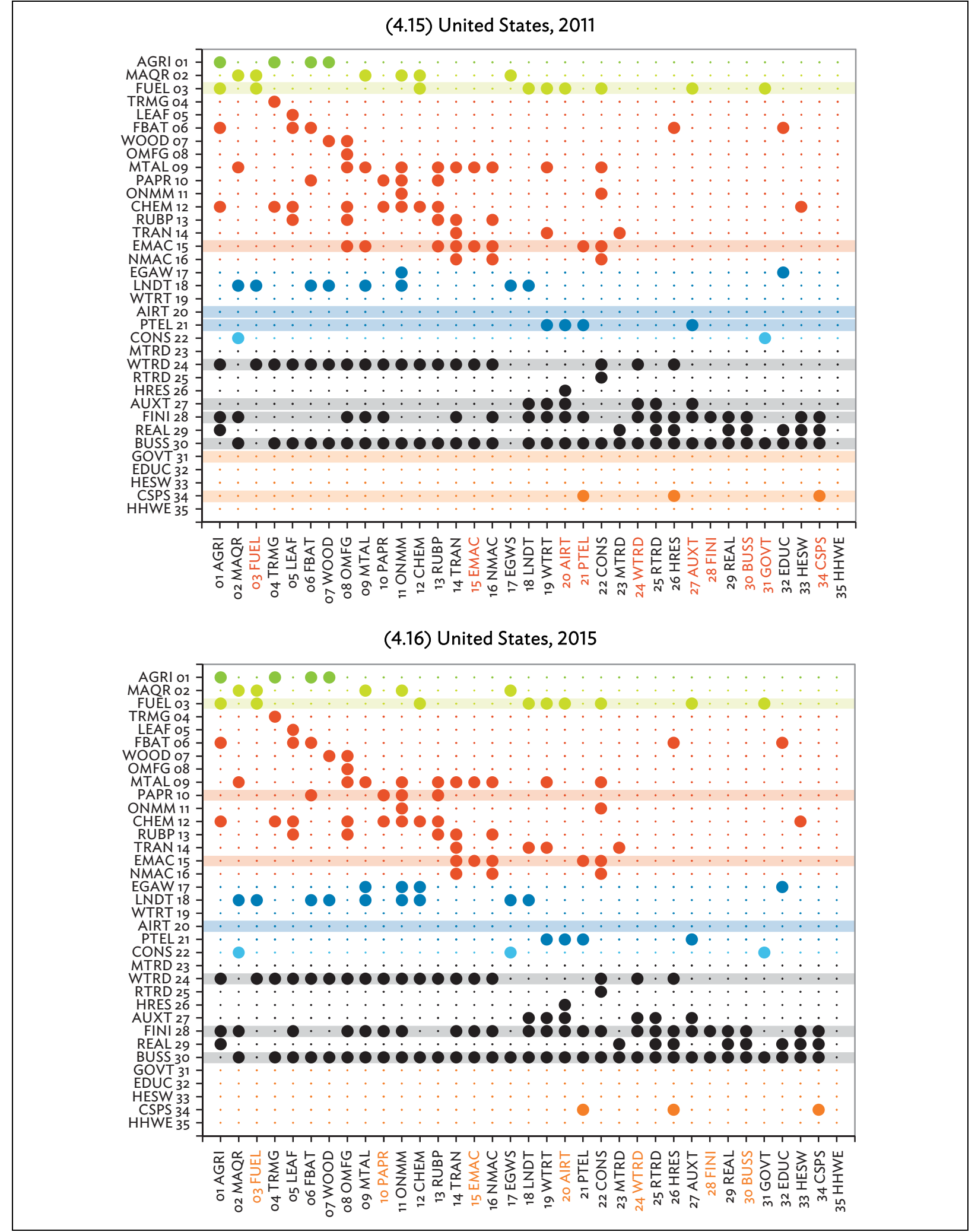


(4.17) Viet Nam, 2000

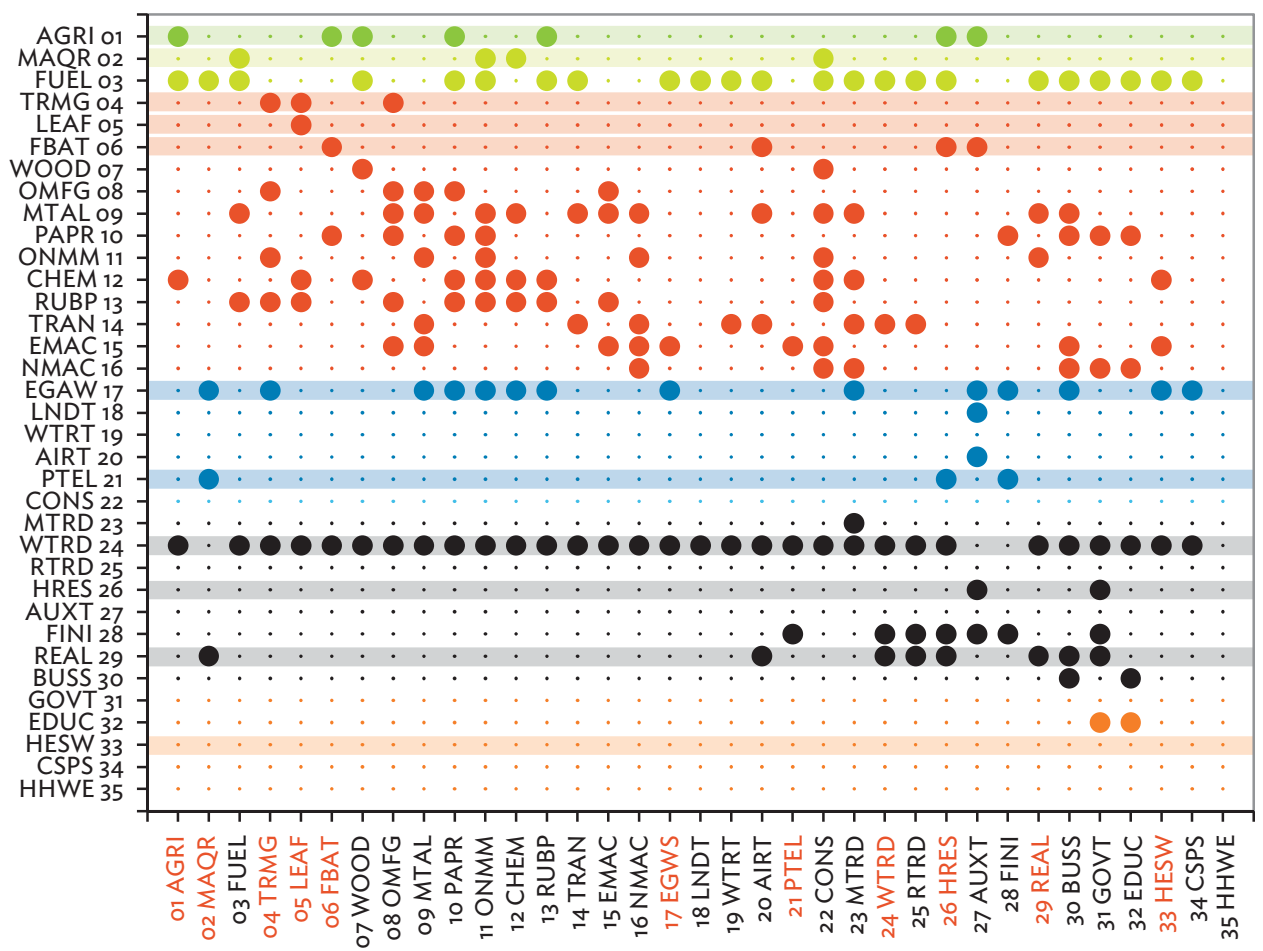

(4.18) Viet Nam, 2006

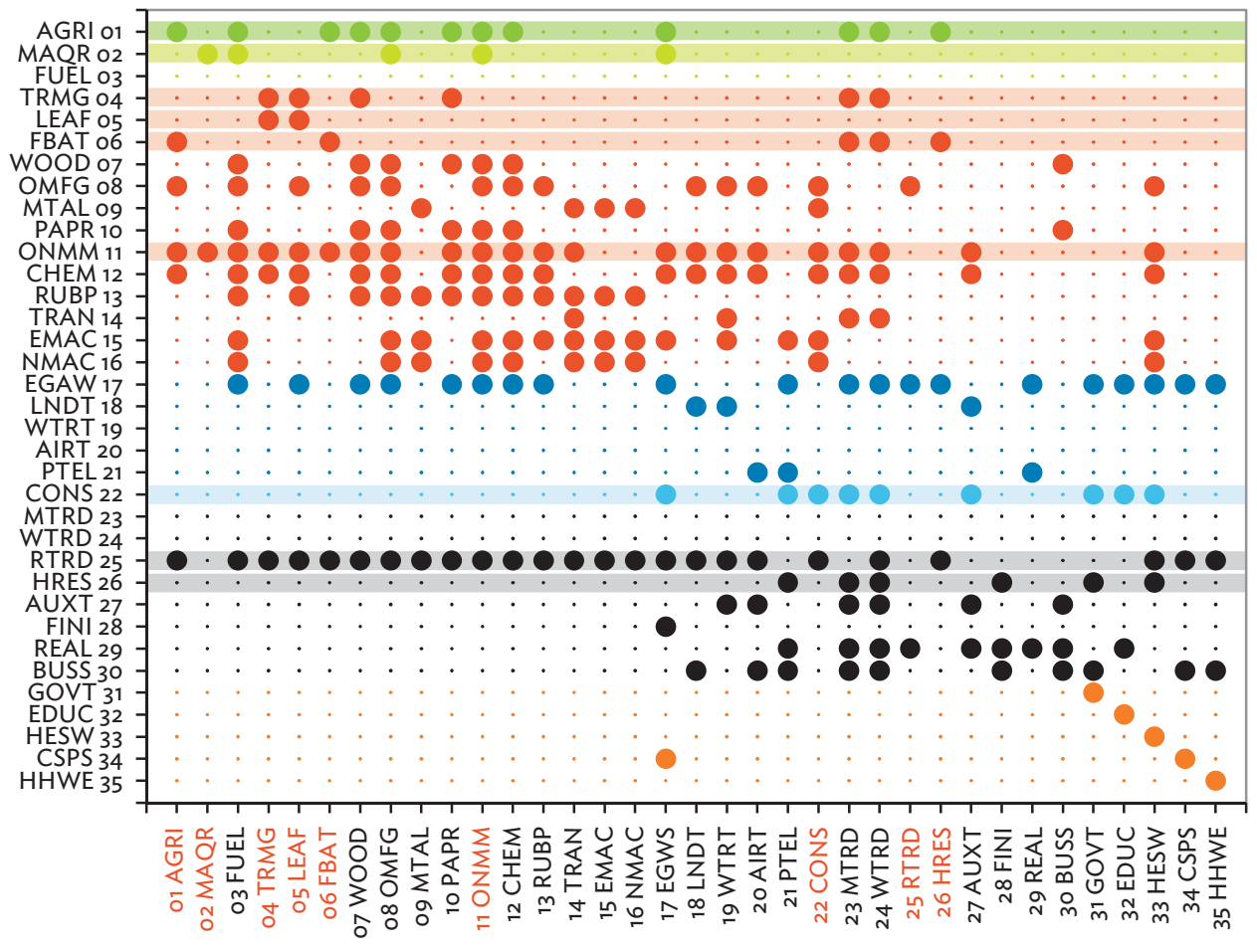




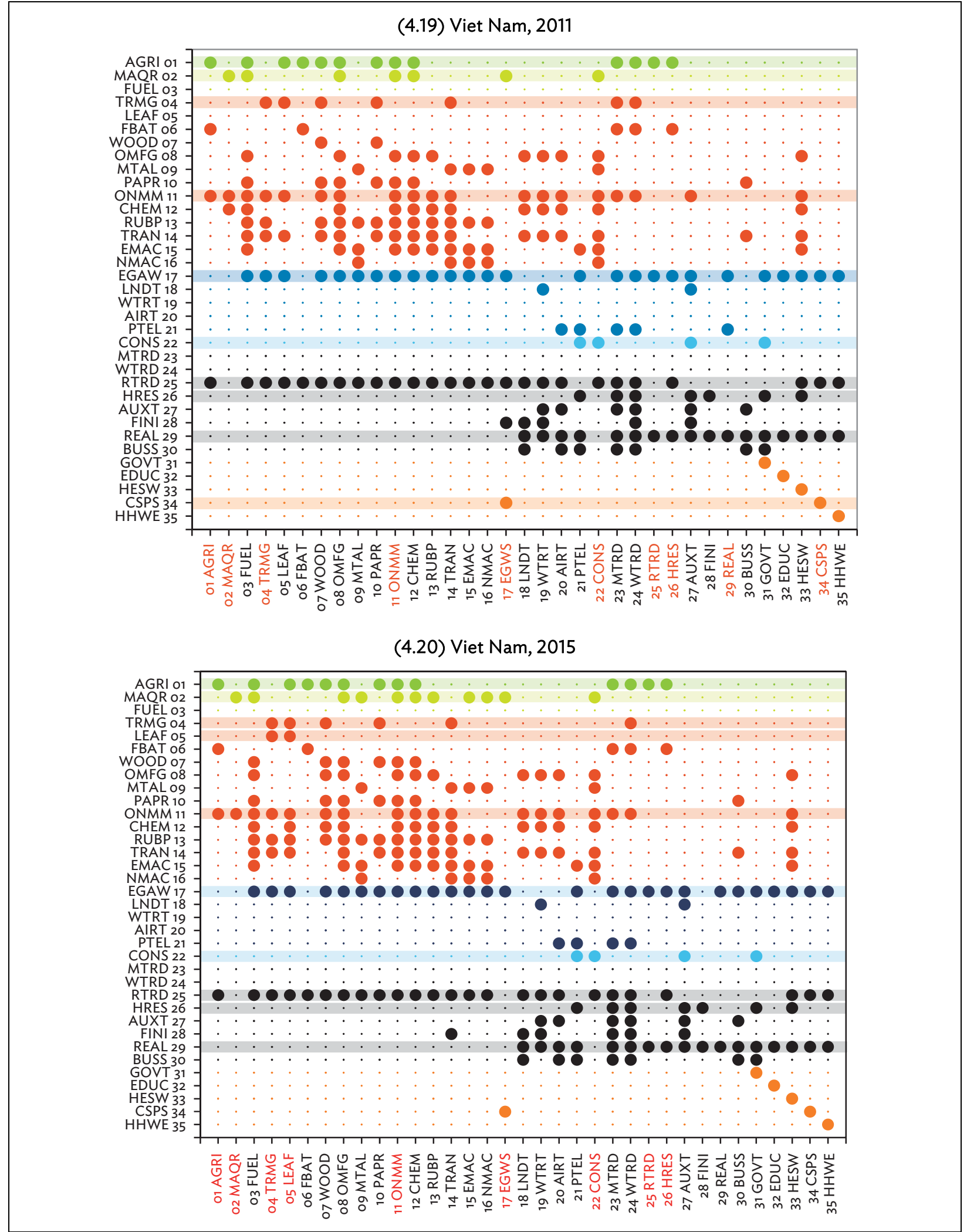


Figure 4 continued

\begin{tabular}{|c|c|}
\hline \multicolumn{2}{|c|}{$\begin{array}{l}\text { Input-Output Descriptions and Sectors } \\
\text { Agriculture } \\
\text { Natural resources } \\
\text { Manufacturing } \\
\text { Infrastructure service } \\
\text { Construction (HH, GOV, GFCF) } \\
\text { Business services } \\
\text { Government and community service }\end{array}$} \\
\hline $\begin{array}{l}\text { AGRI = Agriculture, hunting, fishery, and forestry } \\
\text { MAQR = Mining and quarrying } \\
\text { FUEL = Fuel products } \\
\text { TRMG = Textiles and ready-made garments } \\
\text { LEAF = Leather products and footwear } \\
\text { FBAT = Food, beverage, and tobacco } \\
\text { WOOD = Wood products and cork } \\
\text { OMFG = Manufacturing, nec, and recycling } \\
\text { MTAL = Metal products } \\
\text { PAPR = Pulp, paper, and services } \\
\text { ONMM = Other nonmetallic mineral } \\
\text { CHEM = Chemical products } \\
\text { RUBP = Rubber and plastics } \\
\text { TRAN = Transport equipment } \\
\text { EMAC = Electrical and specialized equipment } \\
\text { NMAC = Nonelectrical machinery } \\
\text { EGAW = Electricity, gas, and water }\end{array}$ & $\begin{array}{l}\text { LNDT = Inland transport } \\
\text { WTRT = Water transport } \\
\text { AIRT = Air transport } \\
\text { PTEL = Post and telecommunications } \\
\text { CONS = Construction } \\
\text { MTRD = Motor vehicles trade and services } \\
\text { WTRD = Wholesale trade } \\
\text { RTRD = Retail trade } \\
\text { HRES = Hotels and restaurants } \\
\text { AUXT = Auxiliary transport activities } \\
\text { FINI = Financial intermediation } \\
\text { REAL = Real estate activities } \\
\text { BUSS = Business activities } \\
\text { GOVT = Public administration } \\
\text { EDUC = Education } \\
\text { HESW = Health and social work } \\
\text { CSPS = Social and personal services } \\
\text { HHWE = Households with employed persons }\end{array}$ \\
\hline \multicolumn{2}{|c|}{$\begin{array}{l}\text { HH = household, GFCF = gross fixed capital formation, GOV = government, nec = not elsewhere classified. } \\
\text { Note: The figures plot input-output total requirements matrix defined as the amount of economy output used per dollar of output of } \\
\text { industry } i \text { (column } i \text { ). We only plot linkages with at least } \$ 0.02 \text { per dollar of output. See a more formal derivation of the direct } \\
\text { requirements matrix "A" in ADB. 2015. Key Indicators for Asia and the Pacific 2015: Part IV: Global Value Chains: Indicators for International } \\
\text { Production Sharing. Manila. (Appendix technical note, p. 374). } \\
\text { Sources: For data used in the dot-plot matrixes: World Input-Output Database. http://www.wiod.org/new_site/database/wiots.htm } \\
\text { (accessed January 2016); and ADB calculations. }\end{array}$} \\
\hline
\end{tabular}

The extent of interindustry demand, of course, does not necessarily have any discernible direct relationship to the growth of the value added or export potential of the sector. However, if one sector depends on some other sectors for supplies, and these sectors in turn increase their demand for other sectors' products, domestic output will increase. Such supply-and-use or input-output links could set the stage for a faster and dynamic structural transformation in the local economy, and could lead to greater diversification.

Conversely, a hypothetical "enclave" sector that only demands inputs from itself, is vertically integrated, and is responsible for the bulk of exports (an extreme case of nondiversification) would be the only sector to create domestic demand for inputs, as represented in the dot-plot matrix where each dot represents a significant technical coefficient (Figure 5). 


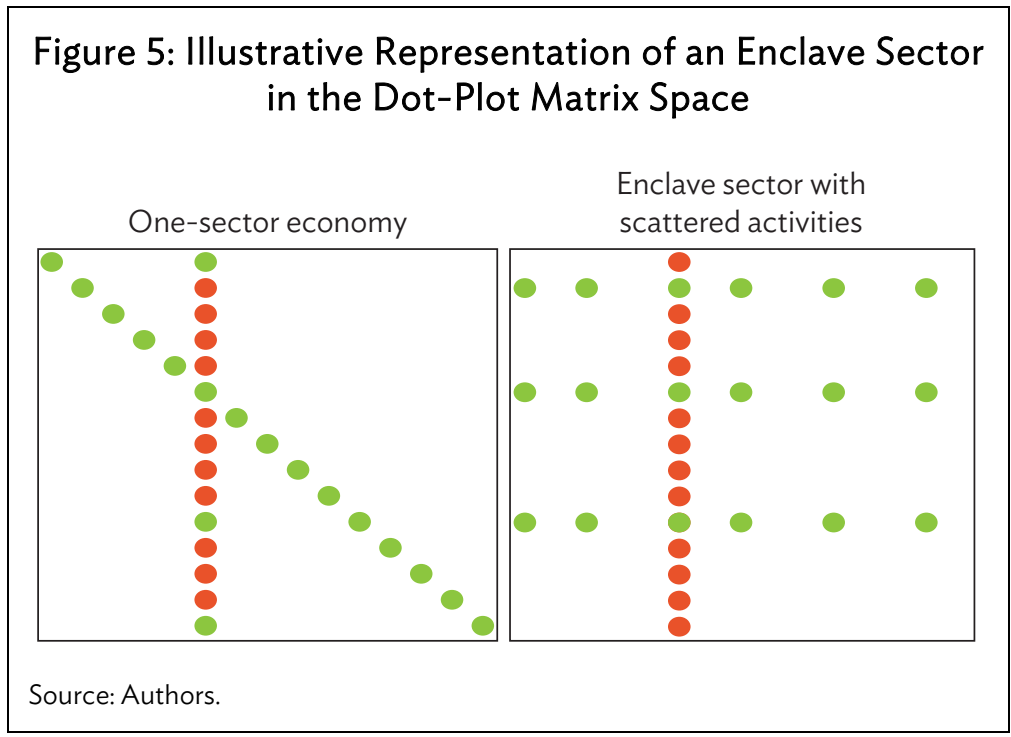

How does the structural transformation evolve in input-output tables? Initially a nascent sector like RMG is likely to have only basic linkages to a few other manufacturing sectors (its suppliers), as well as transport and trade services. However, an economic ecosystem is likely to develop to support the RMG sector. With new investments and without policy or institutional distortions, other similar manufacturing sectors will begin to develop to take advantage of the ecosystem and the business opportunities it presents. Further, as the economy develops, it is possible that even business services such as renting of transport equipment, which at first caters mostly to the RMG sector, will also begin to develop and mature. It could then end its dependence on RMG in particular, and on manufacturing in general, and establish its own forward and backward linkages with other sectors-including the external sector. Increasingly, many sophisticated services cater to high-end manufacturing (Crozet and Milet 2015). Moreover, the country could establish new services to support exports directly and indirectly, and develop a revealed comparative advantage in certain portions of a global value chain but without directly exporting a product (as measured by the NRCA).

We illustrate a representation of the Bangladesh economy and the other four comparator countries in the dot-plot matrixes (Figure 4). They illustrate patterns based on the input-output tables for 2000, 2006, 2011, and 2015. Put simply, the more populated the dot-plot matrix, and the more they spread over time toward more sophisticated manufacturing or services, the more economic diversification is occurring in the process of structural transformation. The seven economic activity blocks are illustrated by different colors in the matrix representations in the legend of Figure 4 . The first three blocks produce primary and tradable goods, and the others produce generally, though not necessarily, nontradable services or supporting activities. Of course, the aggregation of the economic activity blocks is the input-output technical coefficients matrix of the economy as a whole. 
However, we need an indicator to represent the degree to which an economy creates backward and forward linkages among its sectors. For example, assume that RMG demands machinery repair services. Over time, if these services expand to provide machinery repair to other sectors in manufacturing, the economy would then have experienced some level of structural transformation. We develop a so-called "index of agglomeration" to measure the extent of the intersectoral linkages in the economy. It is somewhat similar to Fadinger, Ghiglino, and Teteryatnikova (2015), except that we try to differentiate between productive tradable sectors and nontradable or service sectors. ${ }^{6}$ We also disaggregate the analysis by major activity (so-called "economic block"), taking into account the fact that productive sectors like manufacturing and agriculture are more likely to export directly than services such as finance and repair. Of course, at a level of aggregation of 35 sectors per economy, many interactions within the sector cannot be captured, particularly those that may arise from high specialization.

\section{The following observations can be made about Bangladesh:}

(i) The highest demand for intermediate inputs comes from its own sector (to produce garments, one requires textiles). The process under which real value added is created may be strongly linked to the external economy but not at all to the domestic economy (for example, an export processing enclave such as RMG). Nonetheless, its competitiveness in the global market as measured by the NRCA continues to be high and rises throughout the 4 years analyzed.

(ii) Interindustry demand linkages in Bangladesh do not seem to evolve significantly through time, and changes seen in the multipliers are rather insignificant. Manufacturing, for example, did not create substantial backward linkages with supporting sectors (other than with itself).

(iii) More troubling is the still-strong reliance on nonproductive areas such as government and community services in Bangladesh. This is evident in the number of forward linkages from the "government and community services" sector to manufacturing. This contrasts strongly with the weakness of the linkages with other sectors. The correct interpretation would be of a bureaucracy that is intervening to a high degree in the productive sectors, not that the country has a revealed comparative advantage in a public good. Some of this could reflect the prevalent and strong presence of nongovernment organizations and the donor community in Bangladesh, but it could also reflect the still-strong intervention of the state in many economic activities.

We compare the Bangladesh experience with four other countries. To understand how these patterns may differ from those of countries that are many years ahead of Bangladesh in structural transformation, we conduct a similar exercise for four more countries: Viet Nam (which has more diversified exports), the PRC (which is likely one of the most diversified countries in terms of production), India (which has pockets of developed sectors), and the US (as an example of an advanced economy). All of these countries started industrializing at different times, to some extent producing and exporting textiles and garments. We are interested in examining not just linkages of the economy as a whole, but also how the types of sectors interact.

6 Fadinger, Ghiglino, and Teteryatnikova (2015) find that poor countries have more extreme distributions of input-output multipliers than rich economies: there are a few high-multiplier sectors, while most sectors have very low multipliers; in contrast, rich countries have more sectors with intermediate multipliers. Moreover, the correlations of these with productivities and tax rates are positive in poor countries and negative in rich ones. 
(i) All countries (including Bangladesh) have one or two types of infrastructure service that are very important for all sectors and are demanded by almost all product groups. ${ }^{7}$ Transport is demanded by all sectors (inland transport has strong linkages with all sectors, particularly in India and Bangladesh, but not in Viet Nam). Water, gas, and electricity have very strong linkages in the PRC, India, and Viet Nam, but not in Bangladesh (possibly because many manufacturing firms have their own rental power plants). In the US and the PRC, services provide an important demand pull to the "telecommunication and post" sector.

(ii) Business and infrastructure services: In business services, only the US shows strong linkages that are independent of the productive sectors. A large part is related to the growth of leasing in machinery and equipment and business outsourcing. However, India is also competitive in "exports" (in value-added terms) of certain business activities including in information technology software. Not surprisingly, in all countries, distributive services-wholesale and retail trade-clearly have strong linkages with practically all productive sectors. Financial services and real estate services are also prominent, particularly in Bangladesh and India. Of interest is the category of business activities such as rental and leasing of machinery, which is likely a nontraded service.

(iii) The US figures prominently in having strong linkages between business services and telecommunications, and within the business service sectors themselves. In other words, a clear "cluster" around business services has existed throughout 2000 to 2015, the period of analysis. Moreover, the main dot-plot patterns change very little during the period of analysis. The existence of activities that do not depend on the productive sectors (agriculture and manufacturing) is the manifestation of a well-developed service economy. Moreover, the US has a strong revealed comparative advantage in the trade-in value added of this category of business activities. Both the PRC and Viet Nam also show increasingly more agglomeration around business services as they become more important in the economy, but these services are linked mostly to other manufacturing. In other words, their business activities still depend largely on supporting the manufacturing sector. Interestingly, although the domestic linkages of business activities for the case of India are not very strong, as with the US, the comparative advantage is in the value-added export of this business sector. We know that Silicon Valley in the US and Bangalore in India are important centers of software production; this may be partially captured here. ${ }^{8}$

We now need to synthesize what the dot-plot matrix represents in an indicator.

\section{B. Summary Indicator of Agglomeration}

We construct summary indicators of the degree and strength of related linkages, defined as the "agglomeration" index for each economic activity block and for the whole economy. The index numerically summarizes the degree of clustering as a whole and for each economic activity block. It is the formulaic interpretation of the dot-plot matrixes of Figure 4 (differentiated by the color of the dots in the country technical coefficients matrix).

7 These would be measured by the number of forward multipliers, reading horizontally the number of dark blue dots in Figure 4.2.

8 Internet services and software production may appear in various sectors, depending on the type of firm to commission it (post and telecommunications, wholesale services, and "other" services). However, this is the sector most likely to have the subcontracting of such services. 
More formally, we define the agglomeration index of an economic activity "block" $k=1$ to 7 as $A G G_{c, k}$ where $c$ is the country ( $c=1$ to 5 ). There are two components of agglomeration: the first is that formed by "backward" linkages (the number of "dots" along the sector "column" and intensity of a given sector as illustrated in the dot-plot matrixes). We will define this term as $A G G(b)$, the keconomic block of country $c$ as

$$
A G G(b)_{c}^{k}=\ln \left[\sum_{i=1}^{l} m(b)_{i} * \frac{\sum_{i=1}^{l} \quad \sum_{g=1}^{n} p_{g}}{l * n}\right]
$$

where $m(b)_{i}$ is the backward total requirements multiplier of sector $i$, defined as the additional output, in value terms, that must be produced by all the sectors in an economy if sector $i$ is to produce one more unit value of output for final consumption including exports. $m(b)_{i}$ is also the vertical sum of each element in the Leontief inverse matrix for the column corresponding to sector $i$. The variable $l$ denotes the number of sectors in an economic activity block $k$, whereas $n$ is the total number of sectors in the economy. And $p_{i}$ is the indicator of participation, defined as a "significantly important" contributor from the technical coefficients matrix. This particular variable is defined as the metric that indicates whether sector $i$ contributes to the production process of any given sector of the economy, including itself. To denote its significance, $p_{i}$ is a binary variable that takes the value of 1 if the direct requirements coefficient is greater than 0.02 and zero otherwise. ${ }^{9} \mathrm{~A}$ well-diversified economy has a high $p_{i}$.

Essentially, $A G G(b)_{j}^{k}$ describes the degree of agglomeration or clustering of economic activity in a particular economic block (or a particular economy) created by backward (demand) linkages. It provides an indicator, not only of the strength of the linkages among sectors (given by the sum of multipliers, $m(b)_{i}$ ), but also the degree of participation of other sectors in the production of that sector. Hence, in some ways, the product provides a "booster" to the multiplier term if many sectors are involved in production. The extreme counter example is an enclave, which has a high multiplier but only demands from itself (Figure 4). The indicator is expressed in logs to create a more manageable range.

Similarly, we define the term $A G G(f)$ as the agglomeration was formed through forward linkages. The agglomeration indicator for the kth economic block of country $c$ is

$$
A G G(f)_{c}^{k}=\ln \left[\sum_{j=1}^{l} m(f)_{j} * \frac{\sum_{j=1}^{l} \sum_{h=1}^{n} p_{h}}{l * n}\right]
$$

where $m(f)_{i}$ is the "forward" total requirements of a sector $i$, defined as the additional supply. In value terms, that sector $i$ provides to all the sectors in an economy in response to a unit value increase in the final demand for the products of each of the sectors, including itself. $m(f)_{i}$ is also the horizontal sum of each element in the Leontief inverse matrix for the row corresponding to sector $i$. The indicator $p_{i}$ has the same interpretation, except that it boosts the forward multiplier if sector $i$ contributes to the production of many goods or services of the economy (as opposed to just a few). $m(f)_{i}$ is large when sector $i$ provides a large share of the value added consumed or exported. A sector will have a high value of $A G G(f)$ if $m(f)_{i}$ is large and it provides intermediate inputs to the production of many goods and services. We expect that in a vibrant economy, transport, telecommunications, and some business services would have a high value of $A G G(f)$, although $A G G(f)$ and $A G G(b)$ have different interpretations,

9 The direct requirement or technical coefficients matrix generally has a value for each entry, but some are insignificantly small, which for all practical purposes indicates a very weak link to the respective intermediate sector. Therefore, we assume this is statistically not different from zero. We test this for sensitivity and get a slightly different value of the indicator, but qualitatively the same results. 
for the economy as a whole (aggregating all 35 sectors), $A G G(b)=A G G(f)$. For the backward indicator we would be adding along the columns for all 35 demanding sectors $i$ (and for the latter across the rows for all 35 producing sectors $j) .{ }^{10}$ However, we are also interested in the economic blocks, so we compute both $A G G(f)$ and $A G G(b)$ separately, as well as taking the average of the two. Define:

$$
A G G_{c}^{k}=\frac{\left(A G G(b)_{c}^{k}+A G G(f)_{c}^{k}\right)}{2}
$$

Since the hypothesis to be tested is that export sectors that grow quickly will demand from many sectors of the economy, and that services essentially have a supportive function, one would expect the "economic blocks" of agriculture, natural resources, and manufacturing to have high backward linkages for sectors that export, and the service blocks to have high forward linkages. Ideally, productive sectors will have both high forward and high backward linkages of all types.

The participation level of various sectors, represented more broadly in the dot-plot matrixes (Figure 4), shows that participation levels by economic block in Bangladesh are relatively low. Table 2 shows the second part of the "product" expressed in equation 7. It is color coded so that the greener the cell on the color scale, the higher the participation level. For example, 18\% of the activities of the manufacturing sector generate both forward and backward linkages with other sectors (including itself). The first row reports the total for each economy. Viet Nam has the greatest number of direct linkages, particularly in the manufacturing sector, suggesting that their domestic economy is very well diversified. The US has the most linkages in business services (22\% compared with $15 \%$ in Bangladesh). Finally, while the number of linkages in government and community services is very low for all countries, Bangladesh scores considerably higher, at $16 \%$ compared with other countries. The graphic representation of this phenomenon is clear in Bangladesh's dot-plot matrix in Figure 4, with the number of orange dots in Bangladesh, contrasting with the sparseness in other countries.

\section{Table 2: Participation in Production: Share of Active Sectors by Economic Activity, Bangladesh and Comparator Countries, Average for 2000, 2006, 2011, and 2015}

$(\%)$

\begin{tabular}{|c|c|c|c|c|c|}
\hline & Bangladesh & India & PRC & US & Viet Nam \\
\hline Agriculture & 18 & 15 & 21 & 16 & 23 \\
\hline Natural resources & 18 & 18 & 21 & 17 & 18 \\
\hline Manufacturing & 18 & 19 & 19 & 16 & 23 \\
\hline Infrastructure service & 16 & 23 & 15 & 14 & 18 \\
\hline Business services & 15 & 15 & 18 & 22 & 20 \\
\hline Government and community service ${ }^{a}$ & 16 & 4 & 10 & 5 & 9 \\
\hline Total & 16 & 16 & 17 & 15 & 19 \\
\hline \multicolumn{6}{|c|}{$\begin{array}{l}\text { PRC = People's Republic of China, US = United States. } \\
\text { a For India, the relatively low estimates seen for the government and community services block could largely be attributed to the } \\
\text { suppression of government sector related numbers in the input-output tables used in the calculations. If the data could be } \\
\text { disaggregated sufficiently to accurately discern the sector's role in the economy, the estimates for India are likely to be much higher. }\end{array}$} \\
\hline
\end{tabular}

10 In notation, $L=n=k=35$ : the number of sectors in the economic block when the economic block is the full economy is equal to the total economy. We are adding up all the elements in the two components of the product in equations (1) and (2) but in different order. The elements of the Leontief inverse matrix that compose $m(b) i$ are also in $m(f)_{j}$. 
Of course, Table 2 says nothing about the strength of the linkage, as measured by the multiplier effect. Therefore, the results of the agglomeration indicators (applying equations 1, 2, and 3, and averaging across all years) are presented in Table 3. Some general trends are worth pointing out, based on our small and unrepresentative sample of five countries. First, the highest overall values of agglomeration tend to occur in the productive sectors, particularly in manufacturing. Second, other than a few isolated cases, in all countries and all sectors, multipliers increase through time (regardless of the level of development). Third, the PRC and Viet Nam, the most diversified countries, show the highest levels of total agglomeration in manufacturing (3.1 for the PRC and 3.37 for Viet Nam), as well as a core development of business service sectors that decouple somewhat from the manufacturing sector. In contrast, from the dot-plot matrixes in Figure 4, one still observes that business services are strictly dependent on the manufacturing sector in India and Bangladesh.

We can also relate the agglomeration index results to the new trade in value-added revealed comparative advantage. Taking advantage of the dynamic nature of this data, we explore how structural transformation is taking place. In other words, we can infer not only how these patterns change through time, but also how they may herald exports in increasingly higher value-added goods. In 2000, Bangladesh's revealed comparative advantage in "leather and footwear," "textiles and garments," "real estate services," "retail trade," and all sectors that compose government and community services (see shaded lines in the Bangladesh 2000 dot-plot matrix). This means that these sectors produce the most value added embedded in exports relative to the total value added and relative to the same sectors in other countries. If we juxtapose the sectors with a high NRCA and compare how they change across time, the results for Bangladesh show that the sectors with a high NRCA are actually those where there is progressively less demand linkages from other sectors. ${ }^{11}$

Table 3 summarizes the results. The higher the index of agglomeration (for any specific economic block comprising a set of sectors with similar production characteristics), the more integrated and linked sectors are, and the higher the number of sectors that "take part" in those linkages. ${ }^{12}$ The values are an average for 2000, 2006, 2011, and 2015. The first part shows the "backward" agglomeration index for agriculture, natural resources, and manufacturing. The second shows the forward agglomeration for the three blocks of services. The final part shows the total agglomeration (both forward and backward), applying equation 3.

The results show that Viet Nam scores highest on the agglomeration index, indicating a welllinked economy with many and high-multiplier levels. Not only is it highly diversified, but also those links have fostered growth of similar sectors. There are also spillovers from infrastructure and manufacturing. The PRC's linkages from the natural resources (oil and metals sectors) and manufacturing come out strong. The agglomeration index also shows a very important forward agglomeration for business services in the US compared with other countries, followed by Viet Nam (probably reflecting new software clusters). Business services also happen to be the sectors in which the US-and to some extent India-has a clear comparative advantage in embodied value added (that is, a high NRCA).

11 This is not necessarily detrimental for growth if the level of concentration or agglomeration is occurring within that sector (as indicated by a high "agglomeration" indicator for manufacturing).

12 There are 35 sectors, divided into six economic blocks: (i) agriculture, (ii) natural resources, (iii) manufacturing, (iv) infrastructure services (which includes construction), (v) business support services, and (vi) government and community services. Construction is folded in with infrastructure services. The last column of Table 3 indicates the number of sectors in each economic block. 
Table 3: Index of Agglomeration by Economic Blocks for Bangladesh and Comparators

\begin{tabular}{|c|c|c|c|c|c|c|}
\hline & Bangladesh & India & PRC & US & Viet Nam & $\begin{array}{l}\text { No. of } \\
\text { Sectors }\end{array}$ \\
\hline \multicolumn{7}{|l|}{ Backward agglomeration } \\
\hline Agriculture & 1.78 & 1.24 & 1.89 & 2.82 & 2.37 & 1 \\
\hline Natural resources & 2.50 & 2.22 & 2.87 & 2.34 & 2.71 & 2 \\
\hline Manufacturing & 2.92 & 3.09 & 3.05 & 2.74 & 3.29 & 13 \\
\hline Total & 2.45 & 2.44 & 2.77 & 2.37 & 2.88 & 35 \\
\hline \multicolumn{7}{|l|}{ Forward agglomeration } \\
\hline Infrastructure service & 1.84 & 2.94 & 2.08 & 1.67 & 2.29 & 6 \\
\hline Business services & 2.55 & 2.66 & 2.73 & 3.41 & 2.85 & 8 \\
\hline Government and community service ${ }^{a}$ & 2.58 & $(0.45)$ & 0.40 & $(0.19)$ & 0.05 & 5 \\
\hline Total & 2.45 & 2.44 & 2.77 & 2.37 & 2.88 & 35 \\
\hline \multicolumn{7}{|l|}{ Total agglomeration } \\
\hline Agriculture & 2.71 & 2.25 & 2.93 & 2.43 & 3.19 & 1 \\
\hline Natural resources & 2.66 & 2.74 & 3.26 & 2.68 & 2.60 & 2 \\
\hline Manufacturing & 2.62 & 2.66 & 3.10 & 2.42 & 3.37 & 13 \\
\hline Infrastructure service & 2.25 & 2.79 & 2.49 & 2.08 & 2.56 & 6 \\
\hline Business services & 2.10 & 2.09 & 2.55 & 2.63 & 2.69 & 8 \\
\hline Government and community service ${ }^{a}$ & 2.12 & 0.33 & 1.44 & 0.71 & 1.17 & 5 \\
\hline Total & 2.45 & 2.44 & 2.77 & 2.37 & 2.88 & 35 \\
\hline \multicolumn{7}{|c|}{$\begin{array}{l}\text { () = negative, PRC = People's Republic of China, US = United States. } \\
\text { a For India, the relatively low estimates seen for the government and community services block could largely be attributed to the } \\
\text { suppression of government sector related numbers in the input-output tables used in the calculations. If the data could be } \\
\text { disaggregated sufficiently to accurately discern the sector's role in the economy, the estimates for India are likely to be much higher. } \\
\text { Note: The index of agglomeration measures the strength of the economic linkages of each type of economic block, including the } \\
\text { total economy, and scores highly when linkages have a strong degree of participation or diversification across the economy. } \\
\text { Source: ADB estimates. }\end{array}$} \\
\hline
\end{tabular}

Manufacturing in Bangladesh does not seem to stand out with particularly strong backward agglomeration, at least relative to the other developing countries. What is striking is that the value for government and community services seems significantly larger than for any other country. Forward agglomeration in business services seem to be considerably well developed, better than one would have initially expected, and are mostly in financial intermediation (where there is considerable foreign direct investment and microcredit) and real estate services.

\section{Dynamic Patterns and Development}

The hypothesis being developed so far would suggest that, as countries develop, their links between manufacturing and business services should be negligible at the cusp of the industrial development, when linkages within manufacturing are strong. Nonetheless, they become stronger as the country's share of services grows and it becomes more developed. Moreover, as countries develop, their links between business services should become stronger.

The tradable sectors (agriculture, manufacturing, and natural resources) that have high agglomeration indexes in 2000 should not only have a revealed comparative advantage by 2015, but also strong links with business services.

Although we have only five countries and four data points across time, we test these two hypotheses by looking at the relationship. First, we take every manufacturing sector's backward multiplier with business service sectors. The results in Figure 6 show that each country does seem to have higher linkages on average as it develops, although all start at different levels likely reflecting their different economic structures. Business-to-business linkages certainly have a strong positive correlation 
to economic development (Figure 6), supporting the important role of sophistication of services in development. Interestingly, the changes in the US from year to year are marginal, whereas more important transformations are displayed in the other countries during the period analyzed, particularly in Bangladesh. Also, the PRC seems to display more of a U-shape, in which the linkages between manufacturing and business fell and then more recently began to rise.

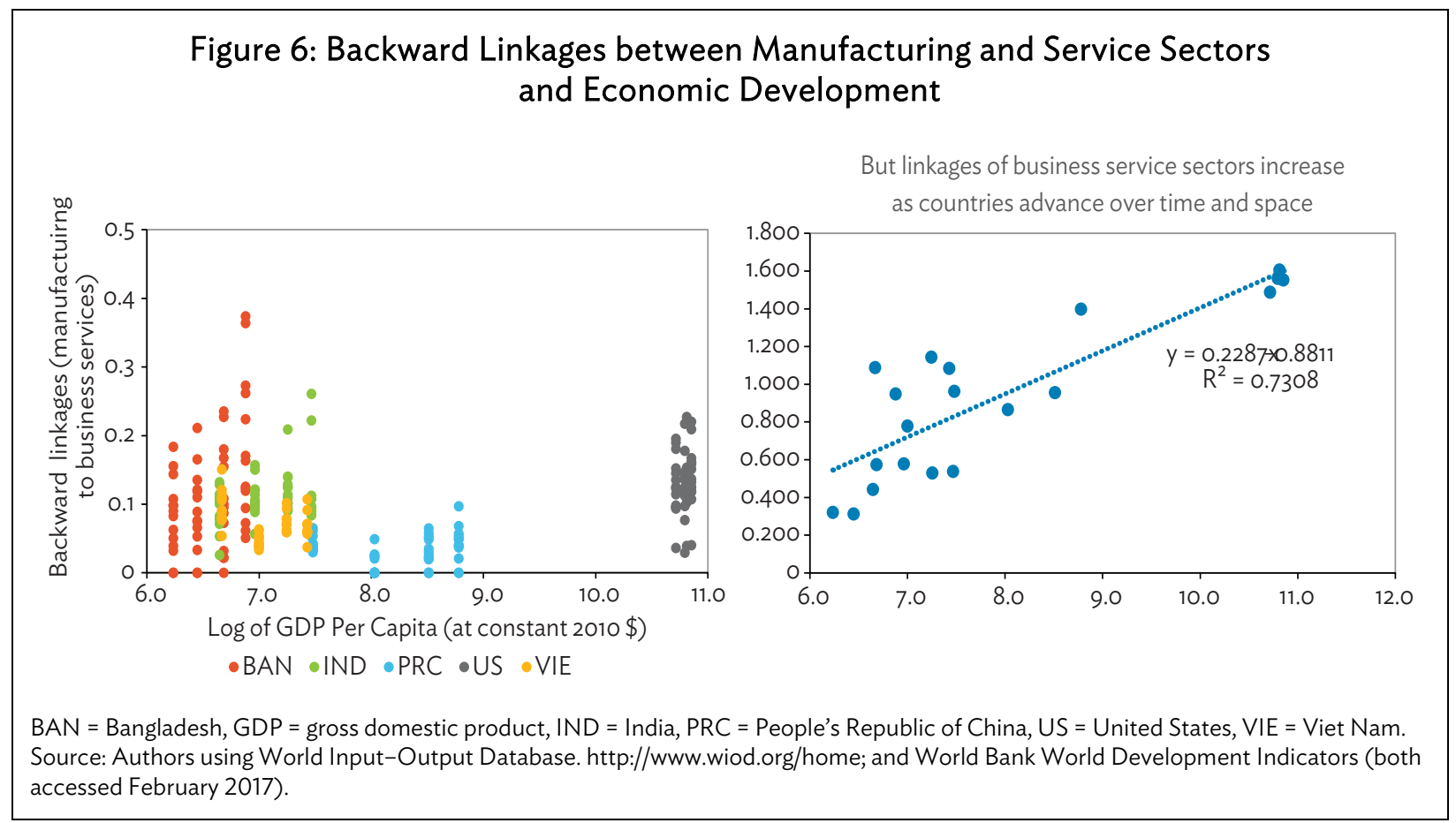

\section{Promising Sectors in Bangladesh}

So far, we have said little about which sectors have developed significant agglomeration in Bangladesh. After analyzing the input-output data, we find that machinery, the sector with the highest multiplier (3.92) in Bangladesh, happens to be the sector in highest demand by the "sale, maintenance, and repair of motor vehicles" (which is a business service). None of these sectors are exported services, and they make up only under $0.25 \%$ of gross value added. However, ADB (2016b) and anecdotal evidence suggest that the country is becoming quite skilled in machinery, particularly in the repair of transport equipment. Most likely, this is because, given low per capita income, the average Bangladeshi finds it too expensive to import vehicles, and instead skills have been developed for the repair, maintenance, and retrofit of existing domestic vehicles, which consequently prolongs the useful life of transportation equipment in Bangladesh compared with other countries. The input-output analysis also shows linkages in specialized electrical equipment and transport equipment, which may include an infant shipbuilding industry. While some of these connections may be speculative, looking at the evolution of links across sectors in other countries may also help to project the direction Bangladesh could or should take toward greater economic diversification and production sophistication. Furthermore, these observations confirm that this type of horizontal diversification-moving to produce something similar to garmentsmay be easier and more natural than moving up the segmented global value chain of the fashion industry. 


\section{E. Is Bangladesh Inserted into Global Value Chain?}

In addition to the relatively few linkages of the domestic sectors, we also find evidence that Bangladesh has been unable to link to global production chains. Global production processes generally do not rely on Bangladesh for intermediate products; hence, the country does not benefit from the feedback effects of an increase in final demand for its products. One could argue that the country is well inserted into the fashion industry value chain because it produces garments, but it is a highly segmented value chain given the way the industry operates.

A salient feature of an input-output table is that it provides the mechanism for detailing the direct and indirect linkages between production and trade. We analyze how a $\$ 1$ million increase in the demand for final products that are produced in Bangladesh affects the country's economy in terms of total change in output by aggregate sectors. Since every sector-specific production process can be represented as a linear combination of the contributions of all industry sectors, the intermediate-use table and the associated table of technical coefficients (A) are square (ADB 2015). ${ }^{13}$ A powerful economic analytical tool known as the Leontief inverse can be derived from the technical coefficient table or matrix $(A)$. Formulaically, it is expressed as

$$
L=(I-A)^{-1}
$$

where $l$ is the identity matrix whose dimensions are the same as that of $A$. $L$ is also known as the total requirements matrix, whereas the matrix of technical coefficients, $A$, is also referred to as the direct requirements matrix. The matrix of total output $X$ (accounting for all direct and indirect effects) required to support final demand $F$ is given by

$$
X^{r}=\left(I-A^{r r}\right)^{-1} F^{r}
$$

where $r$ refers to the economy being analyzed. $A^{\text {rr }}$ is the technical coefficient matrix of transactions within $r$.

The total requirements matrix, $L$, can be decomposed into three components based on the intrinsic cause (demand) driving the production of the output: intraregional effect $\left(M_{1}\right)$, interregional spillover effect $\left(M_{2}\right)$, and interregional feedback effect $\left(M_{3}\right)$, where

$$
L=M_{3}{ }^{*} M_{2}{ }^{*} M_{1}
$$

wherein

(i) $\quad M_{1}$ captures the total output that a sector must produce to meet the total intraregional requirement for its output arising from a unit value increase in final demand for any given commodity in any given location;

(ii) $M_{2}$ measures the pure interregional direct and indirect demand for the sector's product; and

(iii) $M_{3}$ shows the demand of a sector or economy for its own product(s) resulting from its product(s) being used in the production of commodities, which themselves are demanded by the sector or economy in question for its production process.

13 See ADB (2015) for a detailed exposition of derivations, estimation, and analysis based on input-output tables. 
The results are presented in Table 4, which shows the economic impact by intraregional, interregional, and feedback effects of a $\$ 1$ million increase in the demand for products of any given sector produced in Bangladesh for the 4 years: 2000, 2006, 2011, and 2015. The estimates indicate that generally the production processes of any given sector in Bangladesh are highly localized $\left(M_{1}\right)$, noticeably dependent on imports $\left(M_{2}\right)$, and contribute very little to those of other countries directly $\left(M_{2}\right)$ or indirectly $\left(M_{3}\right)$. The RMG sector is the one instance in which Bangladesh is integrated with the global value chain, but at a low stage of the value chain, and for a final product (apparel). However, between 2011 and 2015, the trends (in $M_{3}$ ) indicate that the country's participation in the global production chains in every sector increased notably through stronger domestic and interregional intersectoral linkages although the feedback effect in terms of levels is significant only for the manufacturing block that encompasses the garment manufacturing sector.

\section{Table 4: Decomposed Effect of a $\$ 1$ Million Increase in Final Demand of Products in Bangladesh's Various Sectors}

(\$)

\begin{tabular}{|c|c|c|c|c|c|c|}
\hline \multirow[b]{2}{*}{ Economic Block } & \multicolumn{3}{|c|}{2000} & \multicolumn{3}{|c|}{2006} \\
\hline & $M_{1}$ & $M_{2}$ & $M_{3}$ & $M_{1}$ & $M_{2}$ & $M_{3}$ \\
\hline \multicolumn{7}{|c|}{ Effect on Economic Block in Bangladesh } \\
\hline Agriculture & $1,244,295$ & 0 & 6 & $1,244,733$ & 0 & 5 \\
\hline Natural resources & $1,367,127$ & 0 & 6 & $1,403,652$ & 0 & 5 \\
\hline Manufacturing & $1,690,257$ & 0 & 40 & $1,744,493$ & 0 & 38 \\
\hline Infrastructure services & $1,516,317$ & 0 & 15 & $1,584,114$ & 0 & 13 \\
\hline Business services & $1,288,856$ & 0 & 4 & $1,325,397$ & 0 & 4 \\
\hline Public and community services & $1,243,472$ & 0 & 5 & $1,269,828$ & 0 & 5 \\
\hline \multicolumn{7}{|c|}{ Effect on Economic Block in the Rest of the World } \\
\hline Agriculture & 0 & 67,093 & 0 & 0 & 107,675 & 0 \\
\hline Natural resources & 0 & 152,112 & 0 & 0 & 252,806 & 0 \\
\hline Manufacturing & 0 & 351,372 & 4 & 0 & 494,534 & 5 \\
\hline Infrastructure services & 0 & 195,249 & 1 & 0 & 297,057 & 1 \\
\hline Business services & 0 & 76,363 & 0 & 0 & 127,915 & 0 \\
\hline \multirow{2}{*}{ Public and community services } & 0 & 82,083 & 0 & 0 & 128,030 & 0 \\
\hline & \multicolumn{3}{|c|}{2011} & \multicolumn{3}{|c|}{2015} \\
\hline Economic Block & $M_{1}$ & $M_{2}$ & $M_{3}$ & $M_{1}$ & $M_{2}$ & $M_{3}$ \\
\hline \multicolumn{7}{|c|}{ Effect on Economic Block in Bangladesh } \\
\hline Agriculture & $1,809,042$ & 0 & 24 & $1,952,134$ & 0 & 1,115 \\
\hline Natural resources & $1,799,172$ & 0 & 49 & $2,207,132$ & 0 & 1,400 \\
\hline Manufacturing & $2,164,608$ & 0 & 199 & $2,371,187$ & 0 & 4,855 \\
\hline Infrastructure services & $1,594,988$ & 0 & 56 & $1,952,760$ & 0 & 1,456 \\
\hline Business services & $1,516,401$ & 0 & 23 & $1,685,344$ & 0 & 1,264 \\
\hline Public and community services & $1,455,064$ & 0 & 39 & $1,505,397$ & 0 & 1,700 \\
\hline \multicolumn{7}{|c|}{ Effect on Economic Block in the Rest of the World } \\
\hline Agriculture & 0 & 278,216 & 4 & 0 & 530,011 & 231 \\
\hline Natural resources & 0 & $1,021,907$ & 10 & 0 & 474,771 & 146 \\
\hline Manufacturing & 0 & 762,702 & 45 & 0 & 558,564 & 7,824 \\
\hline Infrastructure services & 0 & 572,154 & 11 & 0 & 342,841 & 311 \\
\hline Business services & 0 & 213,085 & 4 & 0 & 268,294 & 294 \\
\hline Public and community services & 0 & 212,031 & 7 & 0 & 209,165 & 538 \\
\hline
\end{tabular}

$M_{1}=$ direct effect of the increased demand for the product(s) of a given sector in Bangladesh on the output of the sector; $M_{2}=$ indirect effect of the increased demand for the product(s) of a given sector in Bangladesh on the output of all the sectors in other countries; $M_{3}=$ indirect effect of the increased demand for the product(s) of a given sector in Bangladesh on the output of the sector realized through intersectoral and interregional linkages.

Source: ADB estimates. 


\section{CONCLUSIONS}

This paper has developed a new methodology using input-output coefficients to show the lack of diversification of a specific economy: Bangladesh. Based on the concentration level of exports (Figure 1), the agglomeration analysis provides another testament to the high and increasing concentration of the domestic economy in ready-made garments and the lack of development of other productive activities. Notably, the leather and footwear sector no longer has the comparative advantage it had in 2000; it is also the sector in Bangladesh manufacturing with the lowest multiplier after "other nonmetallic products."

The index of agglomeration indicates that Bangladesh has been slow in developing economic clusters or ecosystems that enable an economy to eventually move up global production chains. This includes high-tech products and business services, thereby precluding further growth in GDP through trade in intermediate and final products. Achieving economic and export diversification and faster growth in new sectors remain a challenge because infrastructure services are developing slowly and public sector intervention in productive activities is significant. By promoting policies to develop different domestic sectors to meet local and global demand for goods and services and minimize the government's role in the market, Bangladesh can follow the path of more successful economies such as the PRC and Viet Nam.

Moreover, Bangladesh has to find ways for the production processes to contribute more to the creation of skills and human capital. It should no longer be enough to train unskilled workers on the factory floor-garment workers should be trained and given incentives to become middle managers and to play a more integral part in the production process. These are the type of processes that help the sector move up or across the value chain. Eliminating anti-export bias against non-RMG exports to get traction on economic diversification should also be a high priority. Moreover, the disincentive of the tariff system to produce intermediate inputs and instead import them is a manifestation of the lack of insertion into global production chains in Bangladesh.

This paper has also shown a fairly simple way to examine the structural transformation cum diversification of five very different types of countries at different stages of development, which is in line with recent literature on the very important role of services-particularly high-skilled-in economic development (UNCTAD 2016). The demand for services by the manufacturing sector and the movement toward business services as the main creator of employment-both professional and service and maintenance services - is the paradigm of development of the US (Berlingieri 2014). It is also consistent with new studies about "servitization" in which advanced economies are shedding manufacturing jobs and gaining service jobs, but these jobs are direct and indirect intermediate inputs into manufacturing.

Future extensions will include more countries in the analysis and formalize the relationship between economic diversification (represented by the agglomeration index) and the insertion into global value chains (represented by the NRCAs and their decomposition). Moreover, by linking the agglomeration analysis to a sector's capital intensity, its labor use and the average skills of labor, we can also examine the structural transformation of the economy as it pertains to labor migration from one sector to another. 


\section{APPENDIX: TRADITIONAL REVEALED COMPARATIVE ADVANTAGE AND NEW TRADE IN VALUE-ADDED INDICATORS}

The comparative advantage of a particular sector can be measured in absolute terms (just for exports, see equation 7), or in terms of the actual value created by a country. One can modify slightly the specification of revealed comparative advantage (RCA) to represent it as a quotient rather than a difference of the RCA in exports.

Thus, we define TRCA as traditional revealed comparative advantage of country $r^{*}$ as follows:

$$
\operatorname{TRCA} A_{i}^{r}=\frac{\frac{e_{i}^{r^{*}}}{\sum_{i=1}^{n} e_{i}^{r^{*}}}}{\frac{\sum_{t}^{G} e_{i}^{r^{*}}}{\sum_{i}^{n} \sum_{t}^{G} e_{i}^{r^{*}}}}
$$

where $e$ is merchandise exports in US dollars there are $\underline{i}=1$ to $n$ commodities or goods and $t=1$ to $G$ countries. Equation 4 shows that a good $i$ exported from Bangladesh has a revealed comparative advantage if its value compared with other goods exported in the world is higher than the average of that good $i$ relative to other goods exported by any other country. In other words, Bangladesh is able to export a relatively larger share of this product compared with other countries. This has a similar interpretation to the RCA equation 1 discussed earlier.

We can use exactly the same interpretation, except that, instead of using $e=$ total exports, we include only the component of the export in each sector that is value added and originating from that sector. Following Wang, Wei, and Zhu (2014), we denote $d v i x \_f$ as the value-added component of exports $i$.

We define comparative advantage in trade-embodied value added as in equation 8.

$$
N R C A_{i}^{r}=\frac{\frac{d v i x_{-} f_{i}^{r}}{\sum_{i=1}^{n} d v i x_{-} f_{i}^{r}}}{\frac{\sum_{t}^{G} d v i x_{-} f_{i}^{t}}{\sum_{i}^{n} \sum_{t}^{G} d v i x_{-} f_{i}^{r}}}
$$

More details on the derivation and indicators can be found in ADB (2015). 


\section{REFERENCES}

Asian Development Bank (ADB). 2015. Key Indicators for Asia and the Pacific 2015. Manila.

2016a. Country Diagnostic Study: Consolidating Export-Led Growth. Manila.

2016b. Bangladesh: Looking Beyond Garments. Employment Diagnostic Study. Manila.

Bartelme Dominick, and Yuriy Gorodnichenko. 2015. "Linkages and Economic Development." National Bureau of Economic Research Working Paper No. 21251.

Berlingieri, Giuseppe. 2014. "Outsourcing and the Rise in Services." Centre for Economic Performance Discussion Paper No. 1199.

Boehm, Johannes, Swati Dhingra, and John Morrow. 2016. "Swimming Upstream: Input-Output Linkages and the Direction of Product Adoption." Centre for Economic Performance Discussion Paper No. 1407.

Crozet, Matthieu, and Emmanuel Milet. 2015. "Should Everybody Be in Services? The Effect of Servitization on Manufacturing Firm Performance." CEPII Working Paper No. 2015-19. October.

Fadinger, Harald, Christian Ghiglino, and Mariya Teteryatnikova. 2015. "Productivity, Networks and Input-Output Structure: Preliminary and Incomplete." Paper presented at the 2015 Annual Meeting of the Society for Economic Dynamics. Warsaw, Poland. 25-27 June.

Feenstra, Robert, Robert Inklaar, and Marcel Timmer. 2015. "The Next Generation of the Penn World Table.” American Economic Review 105 (10): pp. 3150-82.

Felipe, Jesus, and Utsav Kumar. 2012. "Tracking the Middle-Income Trap: What Is It, Who Is in It, and Why?” Working Paper 715. New York: Levy Economics Institute of Bard College.

Fernandez-Stark, Karina, Stacey Frederick, and Gary Gereffi. 2011. The Apparel Global Value Chain: Economic Upgrading and Workforce Development. Durham, NC: Duke Center on Globalization, Governance and Competitiveness.

Hausmann, Ricardo and Cesar Hidalgo. 2011. "The Network Structure of Economic Output”. Journal of Economic Growth. 16 (4). pp. 309-342.

Hidalgo, Cesar and Ricardo Hausmann. 2009. "The Building Blocks of Economic Complexity". Proceedings of the National Academy of Sciences. 106 (105): 10570-75.

United Nations Conference on Trade and Development (UNCTAD). 2016. Trade and Development Report, 2016: Structural Transformation for Inclusive and Sustained Growth. New York and Geneva: United Nations. http://unctad.org/en/PublicationsLibrary/tdr2016_en.pdf

United Nations Industrial Development Organization. 2011, 2012, 2013. International Yearbook of Industrial Statistics. Edward Elgar. 
36 | References

Wang, Zhi, Shang-Jin Wei, and Kunfu Zhu. 2014. "Quantifying International Production Sharing at the Bilateral and Sector Levels." Office of Economics Working Paper No. 2014-04A. Washington, DC: US International Trade Commission.

Winter, Amos, and Vijay Govindarajan. 2015. "Engineering Reverse Innovations." Harvard Business Review. July-August 2015, pp. 80-89.

World Bank. World Development Indicators. http://data.worldbank.org/data-catalog/world-development -indicators

World Input-Output Database. http://www.wiod.org/new_site/data.htm

World Trade Organization. Statistics Database. http://stat.wto.org/Home/WSDBHome.aspx?Language= 


\section{Using Input-Output Analysis Framework to Explain Economic Diversification and Structural Transformation in Bangladesh}

Using input-output tables, this paper develops a framework for considering economic diversification across manufacturing and services and global value chain insertion as an integral part of economic development. New indicators are developed to characterize the structural transformation that occurs across production sectors and the links required to ensure broad-based development. Bangladesh's export-led growth in the last 2 decades, which has been concentrated in ready-made garments, is also examined.

\section{About the Asian Development Bank}

ADB's vision is an Asia and Pacific region free of poverty. Its mission is to help its developing member countries reduce poverty and improve the quality of life of their people. Despite the region's many successes, it remains home to a large share of the world's poor. ADB is committed to reducing poverty through inclusive economic growth, environmentally sustainable growth, and regional integration.

Based in Manila, ADB is owned by 67 members, including 48 from the region. Its main instruments for helping its developing member countries are policy dialogue, loans, equity investments, guarantees, grants, and technical assistance. 